\title{
An Eschatological Mirror: The Romanesque Portal of Beaulieu-sur-Dordogne
}

\author{
MICHELE LUIGI VESCOVI University of Lincoln
}

\begin{abstract}
A long-standing historiographic tradition has explained the twelfth-century portal of Saint-Pierre at Beaulieu-sur-Dordogne through the lens of the struggle against heresy, connecting its monumental imagery with the writings of the abbot of Cluny, Peter the Venerable, specifically his treatises Liber adversus Iudeorum and Contra Petrobrusianos. In this article, the unusual program of the portal is explored in light of Cluniac liturgical readings transmitted by the late eleventh-century lectionary used at Cluny (Paris, Bibliothèque nationale de France, MS nouv. acq. lat. 2246) and other coeval sources. I argue that the portal, informed by these texts, was not only conceived as a visual progression from Lent to Easter but also possibly intended as a mirror, in which the liturgy performed in front of it resonated and was amplified to unveil its deep eschatological meaning.
\end{abstract}

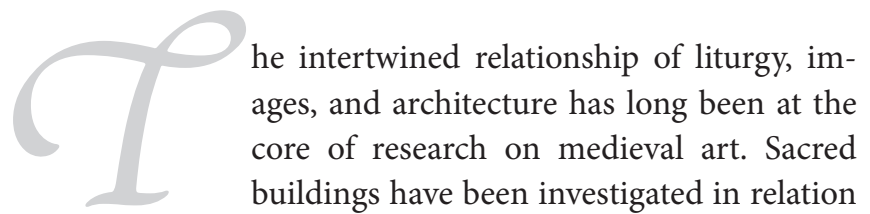
to liturgical functions, and special attention has been paid to the ways that architecture has been conceived to house solemn celebrations based on the liturgy adopted at particular sites. ${ }^{1}$ The impact of liturgy has not been limited exclusively to the architectural settings of the buildings themselves, however. As the work of Paula Lieber Gerson and Margot Fassler, among others, has demonstrated, complex twelfth-century visual programs, such as the portals of Chartres or of SaintDenis, acquire new meanings if considered in light of liturgical readings. ${ }^{2}$

In addition, the work of Mary Carruthers has opened new perspectives on the understanding of images as tools for

This research project inspired an interdisciplinary graduate module at the Centre for Medieval Studies, University of York, where the intense discussions with Lucy Sackville and our students stimulated and sharpened my ideas. A preliminary version was presented at the conference "Lux Nova" in honor of Paula Lieber Gerson (Columbia University, 2014): I am grateful to the organizers, in particular Carey Fee and Jennifer M. Feltman, and to the audience for their feedback. My research also benefited from all my fellow medievalist colleagues at York and Lincoln, especially Michele Campopiano, Jeanne Neuchterlein, Robert Portass, Brooke Shilling, Elizabeth Tyler, and Jamie Wood. I am also extremely grateful to the anonymous reviewers and to the editors of Gesta, Adam S. Cohen and Linda Safran, for their insightful comments. Without the continuous encouragement and subtle criticism of Jessica N. Richardson, this piece would not have been written. I dedicate the article to Arturo Calzona, as a token of gratitude for his constant support and inspiration. Unless otherwise noted, transcriptions from manuscripts and translations are by the author.

1. See, e.g., Carol Heitz, Recherches sur les rapports entre architecture et liturgie à l'époque carolingienne (Paris: S.E.V.P.E.N., 1963); Kristina Krüger, Die romanischen Westbauten in Burgund und Cluny: Untersuchungen zur Funktion einer Bauform (Berlin: Mann, 2003); and Carolyn Malone, Saint-Bénigne de Dijon en l'an mil, "totius Galliae basilicis mirabilior": interprétation politique, liturgique et théologique (Turnhout: Brepols, 2009). Closely related to this topic is the discussion on how the material structures of buildings defined and shaped the pathways of pilgrims and beholders when approaching venerated relics; Paolo Piva, "Lambulacro e i 'tragitti' di pellegrinaggio nelle chiese d'Occidente (secoli X-XII)," in Arte medievale: le vie dello spazio liturgico, ed. Paolo Piva (Milan: Jaca Book, 2012), 81-145.

2. Paula Lieber Gerson, "Suger as Iconographer: The Central Portal of the West Facade of Saint-Denis," in Abbot Suger and Saint-Denis: A Symposium, ed. Paula Lieber Gerson (New York: Metropolitan Museum of Art, 1986), 183-98; Margot Fassler, "Liturgy and Sacred History in the Twelfth-Century Tympana at Chartres," Art Bulletin 75, no. 3 (1993): 499-520; and eadem, "Adventus at Chartres: Ritual Models for Major Processions," in Ceremonial Culture in Pre-Modern Europe, ed. Nicholas Howe (Notre Dame, IN: University of Notre Dame Press, 2007), 13-62. In addition, liturgical ideas informed the mosaic depictions of Roman apses. Marcello Angheben, "Les théophanies composites des arcs absidaux et la liturgie eucharistique," Cahiers de civilisation médiévale 54, no. 214 (2011): 113-41. Discussing the portal of Moissac, Angheben recently highlighted the connection between exterior monumental sculpture and the celebration of the Eucharistic liturgy in the interior of the church: idem, "La théophanie du portail de Moissac: une vision de l'Église céleste célébrant la liturgie eucharistique," in "Le portail roman, XIe-XIIe siècles: nouvelles approches, nouvelles perspectives," Actes des XLVes Journées romanes de Cuxa, 8-13 juillet 2013, special issue, Les cahiers de Saint-Michel de Cuxa 45 (2014): 61-82. 
thought, as dynamic instruments for meditation, in particular through the notion of ductus, the "experience of artistic form as an ongoing, dynamic process rather than as the examination of a static or completed object." ${ }^{3}$ As Carruthers has shown in her analysis of the "mystical mill" of Sainte-Madeleine at Vézelay, this process might involve different objects at various locations in the site: the meditative experience evoked by the different scenes carved on capitals in the south aisle at Vézelay suggests a journey from combat against vices to salvation and triumph. ${ }^{4}$ This methodological approach invites an integrated analysis of medieval buildings, one that has the potential to reveal multiple layers of significance. In his investigation of Chartres, Paul Crossley proposed that we "move from the cathedral as text to the cathedral as experience," highlighting how spaces and objects could have been activated through the movement of the beholders and the dynamics of the liturgy, thus defining sacred pathways in the building itself. ${ }^{5}$ Romanesque portals have a "performative value" that affected the experience of onlookers. ${ }^{6}$

Following Carruthers, the main focus of investigations on the notion of ductus has been the personal journey of a beholder, with emphasis placed on individual engagement rather than on collective ritual experience such as in the form of a liturgical procession. Yet we should certainly ask in what ways monumental images could be activated through the institutional and commemorative performances of a given religious community. Might such a collective experience blur the boundaries between monumental images, the commemorative nature of the performative liturgy, and the events that the liturgy celebrates? In what follows, I explore the Romanesque portal of the abbey of Saint-Pierre at Beaulieu-sur-Dordogne from the perspective of collective performance. I show not only the essential relevance of liturgical readings as a significant source for monumental sculptural programs but also how the sculpted reliefs that frame the portal might

3. Mary Carruthers, "The Concept of Ductus, or Journeying through a Work of Art," in Rhetoric beyond Words: Delight and Persuasion in the Arts of the Middle Ages, ed. Mary Carruthers (Cambridge: Cambridge University Press, 2010), 190-213, at 190.

4. Mary Carruthers, The Craft of Thought: Meditation, Rhetoric, and the Making of Images, 400-1200 (Cambridge: Cambridge University Press, 1998), 92-94, 261-69.

5. Paul Crossley, "Ductus and Memoria: Chartres Cathedral and the Workings of Rhetoric," in Carruthers, Rhetoric beyond Words, 214-49; and idem, “The Integrated Cathedral: Thoughts on 'Holism' and Gothic Architecture," in The Four Modes of Seeing: Approaches to Medieval Imagery in Honor of Madeline Harrison Caviness, ed. Evelyn Staudinger Lane, Elizabeth Carson Pastan, and Ellen M. Shortell (Farnham: Ashgate, 2009), 157-73.

6. Manuel Castiñeiras, "The Romanesque Portal as Performance," Journal of the British Archaeological Association 168, no. 1 (2015): $1-33$.

$54:$ Gesta $\quad$ v56n1, Spring 2017 have mirrored the liturgy performed in front of it, thus reflecting, highlighting, and enhancing its eschatological meaning.

The portal of Beaulieu has played a seminal role in debates about monumental Romanesque sculpture. Émile Mâle claimed not only that this portal was the first "vraie représentation" of the Last Judgment but also that its reliefs served as a model for the central portal of Saint-Denis. ${ }^{7}$ In both portals, the composition is dominated by the large figure of Christ, sitting among the apostles with his arms outstretched, paralleling in his gesture the monumental cross next to him (Fig. 1). ${ }^{8}$ Mâle's comparison has since been called into question, and scholars have highlighted anomalies in the Beaulieu portal, such as the absence of the weighing of souls and the separation of the Elect and the Damned. It has been suggested that the tympanum represents not the Last Judgment but the Second Coming as narrated in Matthew 24-25, the moment that immediately precedes the final judgment. ${ }^{9}$ The identification of the small figures with pointed hats at the feet of Christ as Jews, who draw attention to their circumcisions (Fig. 2), ${ }^{10}$ has led to a reading of the program as antiheretical by connecting the iconography with the writings of Abbot Peter the Venerable of Cluny, specifically his treatises Liber adversus Iudeorum inveteratam duritiem and Contra Petrobrusianos

7. Émile Mâle, Lart religieux du XIIe siècle en France: étude sur les origines de l'iconographie du Moyen Âge (Paris: Colin, 1922), 406-9.

8. Jean-Baptiste Poulbrière, "Léglise et le portail de Beaulieu (Corrèze)," in Congrès archéologique de France, 44th session, 1877, Senlis (Paris: Société Française d’Archéologie, 1878), 582-611, at 601; Eugène Lefèvre-Pontalis, "À quelle école faut-il rattacher l'église de Beaulieu (Corrèze)?," Bulletin monumental 78 (1914): 58-87, at 75; and idem, "Beaulieu," in Congrès archéologique de France, 84th session, 1921, Limoges (Paris: Société Française d'Archéologie, 1923), $366-94$, at 382.

9. Yves Christe, Les grands portails romans: études sur l'iconologie des théophanies romanes (Geneva: Droz, 1969), 173-75; idem, "Le portail de Beaulieu: étude iconographique et stylistique," Bulletin archéologique du Comité des travaux historiques et scientifiques, n.s., 6 (1970): 57-76; idem, La vision de Matthieu (Matth. XXIV-XXV): origines et développement d'une image de la Seconde Parousie (Paris: Klincksieck, 1973); Jochen Zink, "Moissac, Beaulieu, Charlieu: zur ikonologischen Kohärenz romanischer Skulpturenprogramme im südwesten Frankreichs und in Burgund," Aachener Kunstblätter 5657 (1988-89): 73-182, at 128-64; Peter K. Klein, “Et videbit eum omnis oculus et qui eum pupugerunt': zur Deutung des Tympanons von Beaulieu," in Florilegium in Honorem Carl Nordenfalk Octogenarii Contextum, ed. Per Bjurström, Nils-Göran Hökby, and Florentine Mütherich (Stockholm: Nationalmuseum, 1987), 123-44; and idem, "Programmes eschatologiques, fonction et réception historiques des portails du XIIe s.: Moissac-Beaulieu-Saint-Denis," Cahiers de civilisation médiévale 33, no. 132 (1990): 317-49.

10. Henry Kraus, "A Reinterpretation of the 'Risen Dead' on Beaulieu Tympanum," Gazette des Beaux-Arts 107, no. 65 (1965): 193-200. 


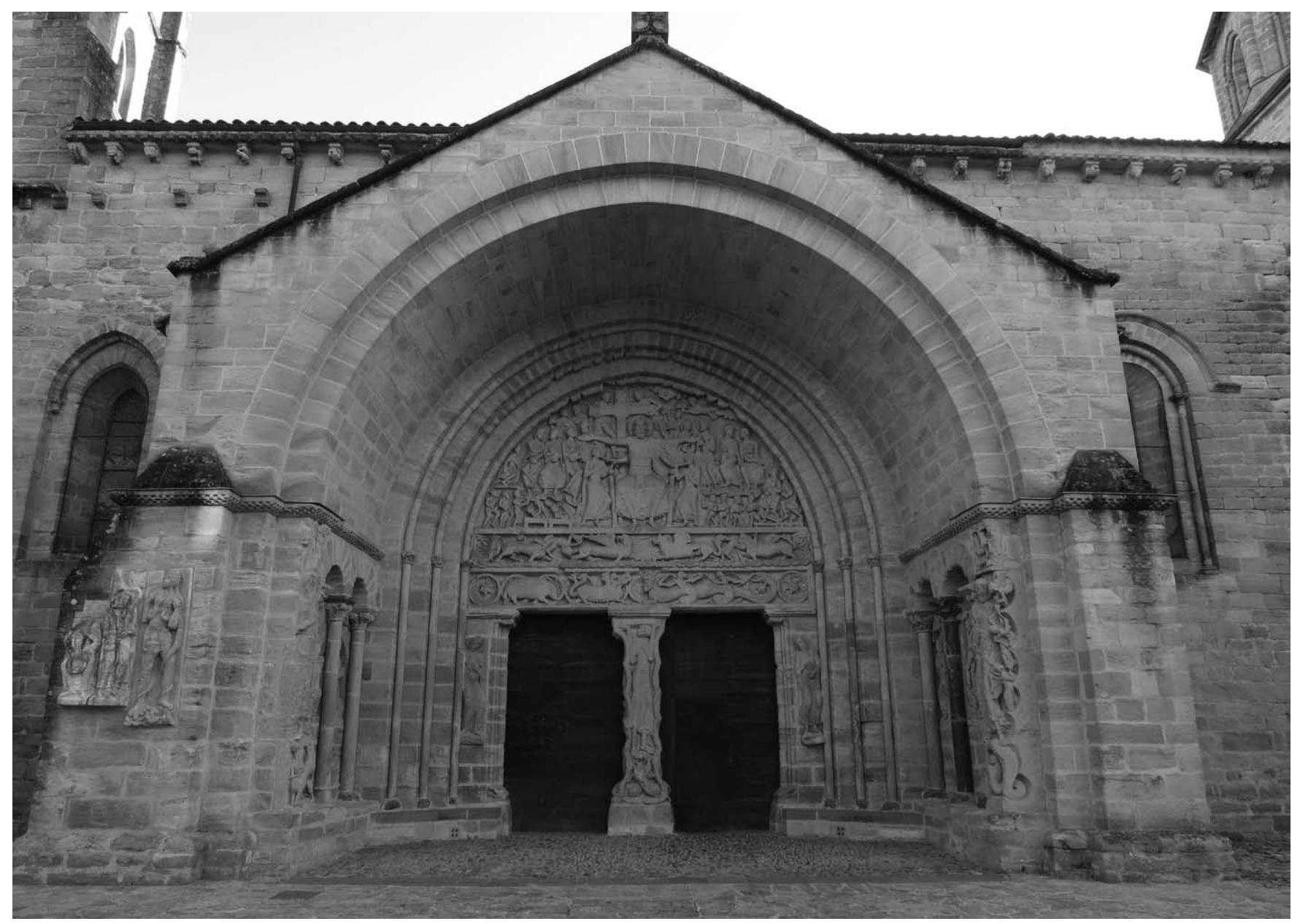

Figure 1. South portal and porch, seen from the south, 1130-40, abbey church of Saint-Pierre, Beaulieu-sur-Dordogne (photo: author). See the electronic edition of Gesta for a color version of this image.

hereticos. ${ }^{11}$ This hypothesis has recently been revived, fusing an antiheretical reading of the program with the idea of the papal reform movement. ${ }^{12}$ The investigation of the tympa-

11. The connection with the writing of Peter the Venerable was first suggested by Christe, "Le portail de Beaulieu," 65-70. This was further developed by Jean Marie French, “The Innovative Imagery of the Beaulieu Portal Program: Sources and Significance" (PhD diss., Cornell University, 1972); and eadem, "The Innovative Imagery of the Beaulieu Portal Program," Studies in Medieval Culture 8-9 (1976): 19-30.

12. Cathrine E. Besancon, "The French Romanesque Portals of Moissac, Souillac and Beaulieu: A Response to the Papal Reform Movement and Popular Heresy" (PhD diss., University of Southern California, 2013). The portal, according to Elizabeth Saxon, "may have been consciously intended to address the heresies of the day, but to see this as its primary purpose is to diminish its triumphal and innovatory assertion of orthodox faith." Saxon, The Eucharist in Romanesque France: Iconography and Theology (Woodbridge: Boydell, 2006), 242. For a detailed critique of the idea of a moral "papal reform" during the decade 1130-40, see Giorgio Milanesi, num is further complicated by the presence of two additional groups of reliefs, framed by arcades in the porch: on the right side the three temptations of Christ (Fig. 3), on the left Daniel in the lions' den (Fig. 4). Scholars have generally argued that these reliefs should be understood as prefigurations of what is depicted in the lunette, in particular Daniel as a type for the triumphant Christ. ${ }^{13}$

These major lines of inquiry are all problematic. Recent scholarship has shown that Contra Petrobrusianos, written shortly before 1138, was modified in 1139-41, and that the core of Liber adversus Iudeorum, first finished in 1144, was revised and completed only in $1147 .{ }^{14}$ Even if its precise date

Bonifica delle immagini e propaganda in Aquitania durante lo scisma del 1130-1138 (Verona: Scripta, 2013).

13. E.g., Zink, "Moissac, Beaulieu, Charlieu," 128-64; French, "Innovative Imagery" (1976); and Saxon, Eucharist in Romanesque France, 238-42.

14. Dominique Iogna-Prat, Order and Exclusion: Cluny and Christendom Face Heresy, Judaism, and Islam, 1000-1150 (Ithaca, 


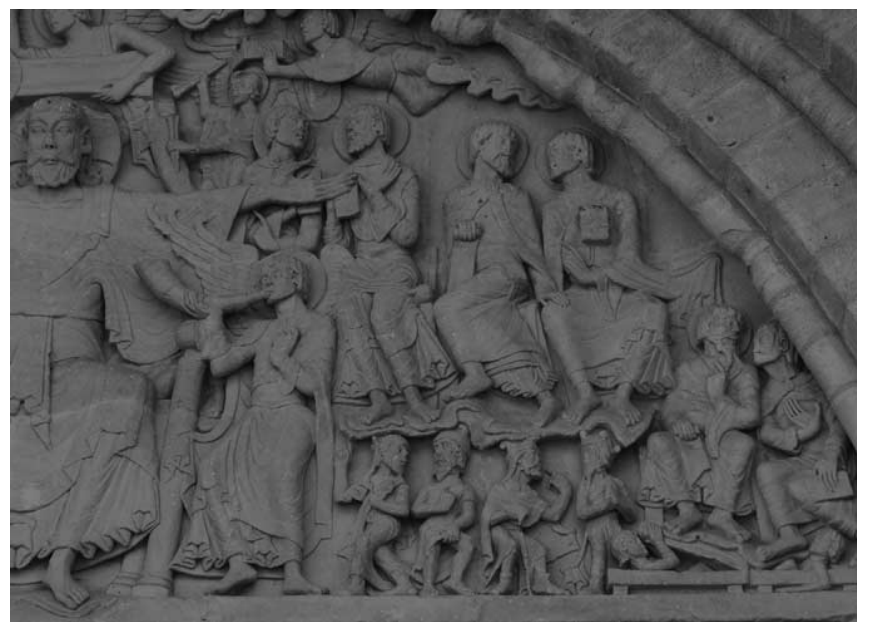

Figure 2. Right half of the tympanum, 1130-40, south portal, abbey church of Saint-Pierre, Beaulieu-sur-Dordogne (photo: author). See the electronic edition of Gesta for a color version of this image.

is not explicitly given in the surviving documents, the portal of Beaulieu likely predates these two texts by Peter the Venerable.${ }^{15}$ Furthermore, Dominique Iogna-Prat has stressed

NY: Cornell University Press, 2002), 116; and Glauco Maria Cantarella, I monaci di Cluny (Turin: Einaudi, 1993), 283-86. In addition, in the hinterland of Toulouse the first manifestations of a struggle against the heresy of Henry of Lausanne took place around the years 1144-47, and Catharism was widespread in Languedoc during the decade 1150-60: André Vauchez, "Les origines de l'hérésie cathare en Languedoc, d'après un sermon de l'archêveque de Pise Federico Visconti (1277)," in Società, istituzioni, spiritualità: studi in onore di Cinzio Violante (Spoleto: Centro Italiano di Studi sull'Alto Medioevo, 1994), 2:1023-36, at 1027. Cathrine Besancon ("French Romanesque Portals," 33-34, 53, 281-82n152) suggests that the condemnation of popular heresy at the Council of Toulouse in 1119 could have served as the impetus for the creation of antiheretical portal programs, in particular at Moissac. Of the ten canons promoted at Toulouse, only one was directed against heretics. Mary Stroll, Calixtus II (1119-1124): A Pope Born to Rule (Leiden: Brill, 2004), 72-74.

15. Anne-Marie Pêcheur and Évelyne Proust, "Beaulieu-surDordogne, abbatiale Saint-Pierre," in Congrès archéologique de France, 163rd session, 2005, Corrèze (Paris: Société Française d’Archéologie, 2005), 83-103, at 98-99. This analysis is informed by the debate on the chronology of the portal of Saint-Pierre of Moissac. However, according to recent studies, the Moissac portal might date slightly earlier than previously thought. Günther Kälberer, "Der Westbau der ehemaligen Abtei Moissac als Beispiel eines Vorhallenturms: ein mittelalterliches Bauwerk im Spannungsfeld funktionaler Anforderungen" (PhD diss., Eberhard-Karls-Universität, Tübingen, 2007); Ilene H. Forsyth, "The Date of the Moissac Portal," in Current Directions in Eleventh- and Twelfth-Century Sculpture Studies, ed. Robert A. Maxwell and Kirk Ambrose (Turnhout: Brepols, 2010), 77-99; and Barbara Franzé, "Moissac et l'oeuvre de l'abbé Ansquitil (1085-1115): un discours de pénitence," Hortus Artium Medievalium 21 (2015): that the Contra Petrobrusianos, of which only three twelfthcentury copies exist, was "not subject to very widespread literary diffusion in the Middle Ages." This text was addressed to the archbishops of Arles and Embrun and the bishops of Die and Gap, all sites that are far from Beaulieu and not in any way connected to it. ${ }^{16}$ Moreover, the interpretation of portal programs as antiheretical propaganda has been called into question, in particular in cases where the heretics themselves are missing or hidden. As Walter Cahn persuasively showed, representations of heretics and/or the Antichrist were always easily recognizable. ${ }^{17}$ At the same time, if the portal is a visualization of the Second Coming, it would constitute an extremely rare iconography in monumental sculpture. Nor does such an interpretation fully take into account all the visual anomalies of the program at Beaulieu, such as the unusual depiction of hell on the lintel or the presence of a thirteenth figure shown sitting with the apostles.

The Beaulieu portal enigmatically integrates carvings that depict the Old Testament, New Testament, and a mysterious vision of the end of time. These have mainly been understood as didactic, political, moralizing, or dogmatic propaganda, but all of these interpretations raise fundamental questions about the audiences and the functions of this liminal space. Did the portal also address a lay audience, or was it conceived mainly in relation to the clergy? How might the monastic community have encountered and experienced this particular space? To explore these questions we need to analyze the tumultuous history of the abbey, which at the time of the completion of the portal was tied institutionally to the great Burgundian abbey of Cluny. Although it is always mentioned in the literature, this link has never been fully explored. To what extent might the unusual program of the portal shed light on the abbey's institutional relationship with Cluny and on the liturgy used in the abbey of Beaulieu? Conversely, to what extent might collective liturgical performance have interacted with the monumental reliefs that frame the sacred threshold of the church?

385-405. For the nineteenth-century restoration of the Beaulieu porch and the replacement of some of the sculptures in 2001-2, see Pêcheur and Proust, "Beaulieu-sur-Dordogne," 84-85, 99-101; and Besancon, "French Romanesque Portals," 246-51.

16. Iogna-Prat, Order and Exclusion, 111-16.

17. Walter Cahn, "Heresy and the Interpretation of Romanesque Art," in Romanesque and Gothic: Essays for George Zarnecki, ed. Neil Stratford (Woodbridge: Boydell, 1987), 1:27-33; idem, "Heresy and Romanesque Art (Again)," in Le plaisir de lart du Moyen Âge: commande, production et réception de l'oeuvre d'art; mélanges en hommage à Xavier Barral i Altet, ed. Rosa Alcoy et al. (Paris: Picard, 2012), 728-34; and Marcello Angheben, "Scultura romanica e liturgia," in Piva, Arte medievale, 147-90, at 168. 


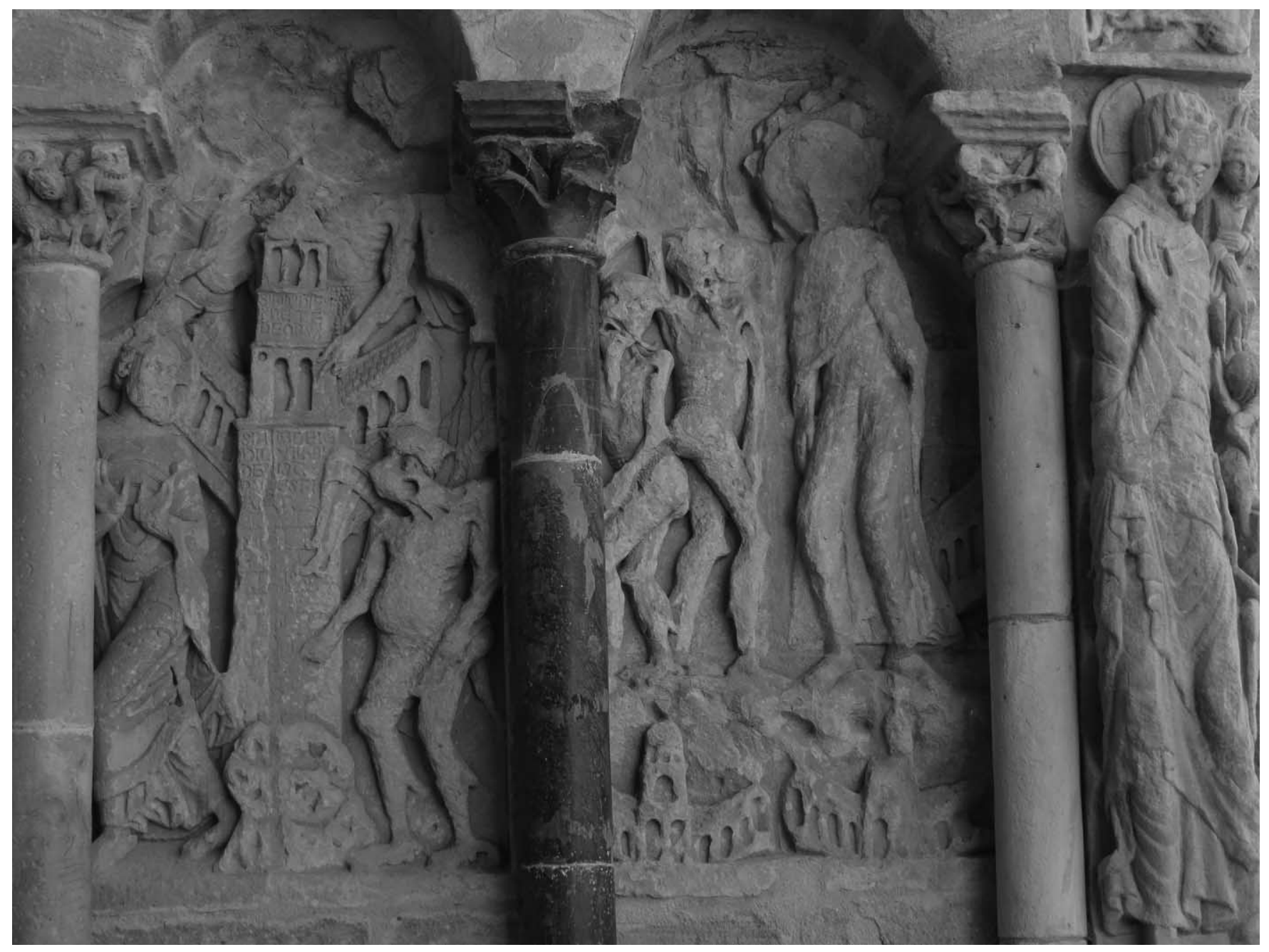

Figure 3. Three temptations of Christ, 1130-40, right flank of the portal porch, abbey church of Saint-Pierre, Beaulieu-sur-Dordogne (photo: author). See the electronic edition of Gesta for a color version of this image.

I examine the portal of Beaulieu in light of liturgical sources, in particular a single manuscript, the late eleventh-century lectionary of Cluny (Paris, Bibliothèque nationale de France, MS Nouvelles acquisitions latines [NAL] 2246, hereafter the Cluniac Lectionary). ${ }^{18}$ In this lectionary, the canonical readings for the major feasts of the liturgical year are paired with

18. On this manuscript, see Raymond Étaix, "Le lectionnaire de l'office à Cluny," Recherches augustiniennes et patristiques 11 (1976): 91-159, at 137-39; François Avril, in La France romane au temps des premiers Capétiens (987-1152), Paris, Musée du Louvre, 10 mars6 juin 2005 (Paris: Musée du Louvre, 2005), 224-25, cat. no. 168; and Fabrizio Crivello, "L'enluminure à Cluny vers 1100 autour de la Bible de Pons de Melgueil," in Cluny, 910-2010: onze siècles de rayonnement, ed. Neil Stratford (Paris: Éditions du Patrimoine, Centre des Monuments Nationaux, 2010), 130-43, at 136. the homilies of Pope Gregory the Great (ca. 540-604). I argue that these texts provide a guide to understanding the unusual combination of images that surround the portal, three monumental scenes that narrate the period from Lent to Easter. The tympanum offers a multilayered depiction that is grounded in the complexity of the liturgical readings. It can be understood as a visual synthesis of liturgical time, a progression that begins in the carvings of the porch. My investigation therefore follows the liturgical path from the porch to the tympanum. As I will demonstrate, the liturgical readings also provide a fresh perspective on the representation of Jews in the portal, who are depicted within a framework of redemption.

Finally, even if the homilies of Gregory the Great circulated widely during the Middle Ages-Raimond Étaix identified 


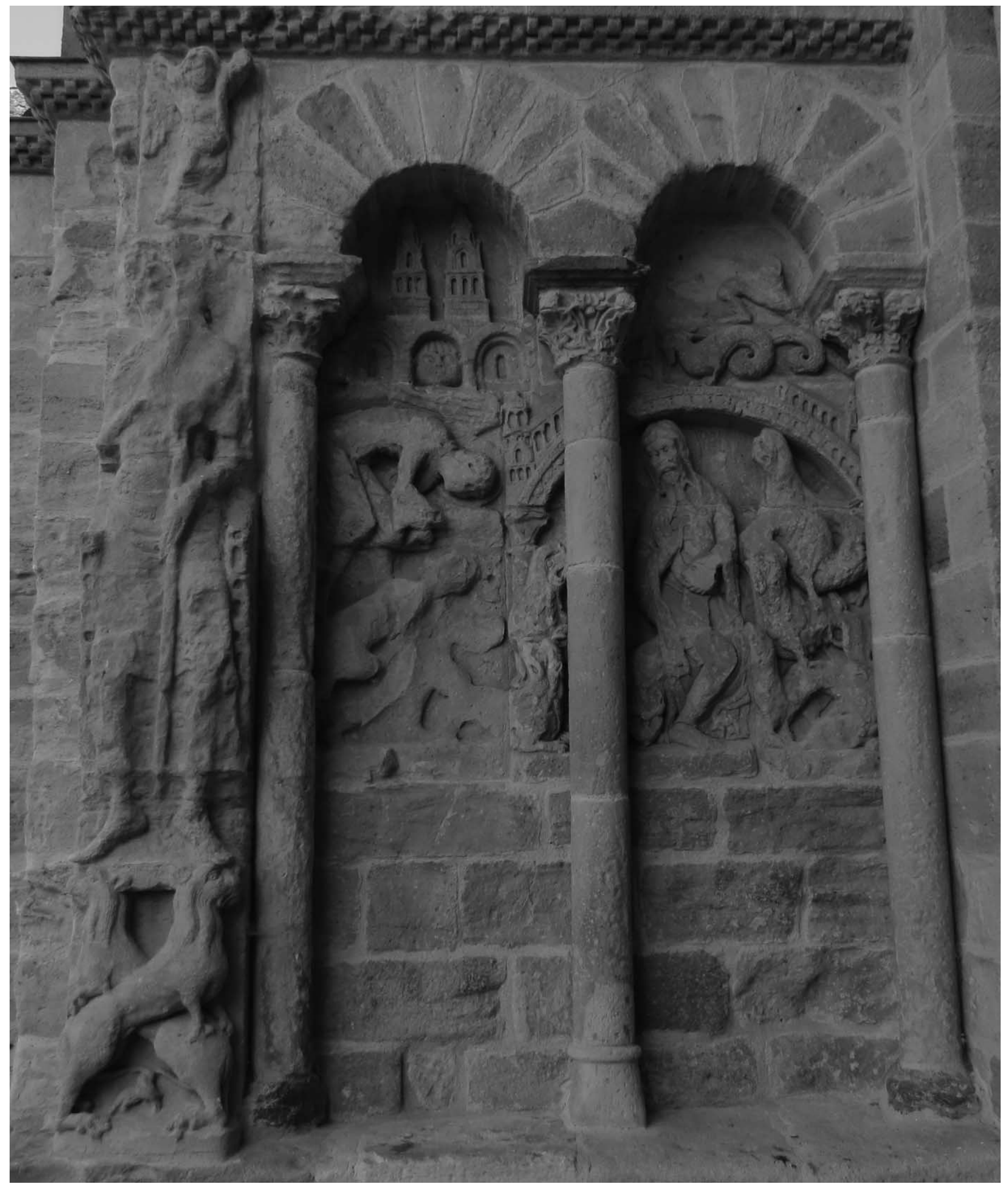

Figure 4. Habakkuk visiting Daniel in the lions' den, 1130-40, left flank of the portal porch, abbey church of Saint-Pierre, Beaulieu-surDordogne (photo: author). See the electronic edition of Gesta for a color version of this image. 
427 copies of the collection produced between the seventh and the fifteenth century ${ }^{19}$ - the Cluniac Lectionary shows that they acquired special significance in the monastic community at Cluny. ${ }^{20}$ In the second part of the essay, I argue that the Beaulieu program resonates with ideas adopted at Cluny, in particular the concept of Galilaea, of which the portal offers a rare monumental visualization.

\section{Beaulieu, Cluny, and the Liturgy}

Two different sources shed light on the history of the abbey of Beaulieu: the material remains of the building itself and the documentary evidence. The monastic site has long suffered. Sacked twice, in 1569 and in 1574, when the majority of relics and liturgical furnishings were burned or stolen, it was abandoned by the monks between 1576 and 1586. After they returned to the site, the community lived in the village because the monastic buildings had been destroyed. ${ }^{21}$ Later the abbey was assigned to the Maurists (French Benedictines), and the coenobitic structure was rebuilt only to be destroyed yet again after the French Revolution.

It is not surprising, considering this tumultuous history, that the documentary evidence from the abbey is scarce and

19. R. Étaix, "Répertoire des manuscrits des homélies sur l'Évangile de saint Grégoire le Grand," Sacris Erudiri 36 (1996): 107-45. For the diffusion of Gregory's homilies and their manuscript tradition, see also Patricia Allwin DeLeeuw, "Gregory the Great's 'Homilies on the Gospel' in the Early Middle Ages," Studi medievali, 3rd ser., 26 (1985): 855-69; Gregory the Great, Homiliae in Evangelia, Corpus Christianorum, Series Latina 141, ed. Raymond Étaix (Turnhout: Brepols, 1999), v-lxxiv; and Thomas N. Hall, "The Early English Manuscripts of Gregory the Great's Homiliae in Evangelia and Homiliae in Hiezechihelem: A Preliminary Survey," in Rome and the North: The Early Reception of Gregory the Great in Germanic Europe, ed. Rolf H. Bremmer Jr., Kees Dekker, and David F. Johnson (Leuven: Peeters, 2001), 115-36.

20. Furthermore, none of the liturgical homiliaries analyzed by Réginald Grégoire presents an exact correspondence between the readings for the Gospel and the homilies of Gregory the Great, as is found in the Cluniac Lectionary. Grégoire, Les homéliaires du Moyen Âge: inventaire et analyse des manuscrits (Rome: Herder, 1966); and idem, "Gli omiliari liturgici," Benedictina 21 (1974): 3-28. Barbara Franzé related the presence of the Jews in the portal to the Moralia in Job of Gregory the Great. Franzé, "Art et réforme clunisienne: le porche sculpté de Beaulieu-sur-Dordogne," Bulletin du Centre d'études médiévales, Auxerre 18, no. 2 (2014), at https://cem.revues .org/13486.

21. Pêcheur and Proust, "Beaulieu-sur-Dordogne," 83. The most vivid description of the devastation during the sixteenth century can be found in an eighteenth-century account of the history of the abbey, Amand Vaslet, "Abregé de l'histoire de l'abbaye de SaintPierre de Beaulieu en Bas-Limousin," ed. J.-B. Poulbrière, Bulletin de la Société scientifique, historique et archéologique de la Corrèze 6 (1884): 59-178. scattered. The library and the archive were probably dismembered during the sixteenth century, and the only collection of medieval documents produced in the abbey, published by Maximin Deloche in 1859, is contained in two later copies of the original cartulaire, which is itself an early thirteenthcentury transcription of the original documents preserved, at the time of Deloche's publication, in a private collection. ${ }^{22}$ The small cartulary (196 charters) probably did not contain all the documents related to the abbey, and it was likely conceived as a guarantee for the possessions of the monastic institution. Nevertheless, it still offers significant insights into the history of the abbey.

Founded between 855 and 858 by Rudolph, archbishop of Bourges and son of the count of Turenne, the abbey of Beaulieu was subsequently donated to monks who followed the Rule of St. Benedict and had the right to elect their abbot freely. The monastery prospered throughout the ninth and tenth centuries. ${ }^{23}$ At the time of the Council of Limoges, in 1031, it was ruled by a lay abbot, nephew of his predecessor. A delegation of monks from Beaulieu expressed concerns over the status of the abbey. The council, having heard their plea, decided that a new abbot should be nominated, while the former lay abbot was allowed to continue as the protector of the abbey. ${ }^{24}$ This resolution was not completely implemented, however, and two further documents show that little changed from the troubled status of 1031. In April 1076, and shortly thereafter, Hugh of Castelnau (who some scholars believe was the lay abbot already in 1031) allowed Cluny and its abbot, Hugh, to establish in Beaulieu "the proper order and the service of God," according to the Rule of St. Benedict. ${ }^{25}$

22. Maximin Deloche, Cartulaire de l'abbaye de Beaulieu (en Limousin) (Paris: Imprimerie Impériale, 1859), v-vi. A manuscript from the cartulary is preserved in Paris, Bibliothèque nationale de France (hereafter BnF), MS NAL 493: Léopold Delisle, Manuscrits latins et français ajoutés aux fonds des nouvelles acquisitions pendant les années 1875-1891 (Paris: Champion, 1891), 2:678; see also Jean Becquet, Actes des évêques de Limoges: des origines à 1197 (Paris: CNRS, 1999), 24-25, 83-84.

23. For the debate on the date of the foundation of the abbey, see Deloche, Cartulaire de l'abbaye, ccxxvi-ccxxx; Robert-Henri Bautier, "Les diplômes carolingiens suspects de l'abbaye de Beaulieu en Limousin," Bulletin philologique et historique (jusqu'à 1610) du Comité des travaux historiques et scientifiques 1955-56 (1957): 37598; and Jane Katherine Beitscher, "Monastic Reform at Beaulieu, 1031-1095," Viator 5 (1974): 199-210, at 200.

24. Anna Trumbore Jones, "Discovering the Aquitanian Church in the Corpus of Ademar of Chabannes," Haskins Society Journal 19 (2007): 82-98, at 90-91; and Beitscher, "Monastic Reform," 201-2.

25. Auguste Bernard and Alexandre Bruel, eds., Recueil des chartes de labbaye de Cluny, 5 vols. (Paris: Imprimerie Nationale, 1876-94), 4 (1888): 600-604, docs. 3490 and 3491 (dated 1076); Deloche, Cartulaire de l'abbaye, xviii-xxvi; and Beitscher, "Monastic Reform," 201-2. 
That decision was followed by twenty years of silence, after which a papal bull promulgated by Urban II on 23 May 1096 and addressed to Hugh, abbot of Cluny, sheds new light on the history of the abbey. ${ }^{26}$ According to the pope, Beaulieu had not followed the monastic rule for a long time, resulting in the damnation of souls because previous pacts were not respected. Therefore, the pope granted the abbey to Hugh so that "the vigor of the monastic order will be repaired in that site." The pope was even more specific when describing the future of the abbey: the abbot of Cluny should rule over Beaulieu "as a member of the Cluniacensis coenobii"; in addition, the abbots of Cluny should continuously establish in Beaulieu abbots from the Cluniac congregation. ${ }^{27}$

This document marks the beginning of a new history for Beaulieu. The formerly independent abbey had now become part of the Cluniacensis Ecclesia; furthermore, Hugh was to nominate the abbot, and it was stipulated that every future abbot of Beaulieu should be a member of the Cluny congregation. The first abbot of this rank, attested in 1097, was Geraldus (r. 1097-1119 or 1130), who appears with the abbot of Cluny, Pontius, in a donation dated 1116-17 in MoustierVentadour, located between Beaulieu and Clermont-Ferrand. Geraldus was followed in the role by Galterius (ca. 1145) and Petrus de Sancto Sereno (r. 1164-90). ${ }^{28}$ Even though the Cluniac connection with Beaulieu lasted only until 1213, it was a significant part of the abbey's history, because that was the very period in which the church was reconstructed and its portal carved. ${ }^{29}$

Basing their work on a close analysis of the architecture and on a wide range of comparisons, Anne-Marie Pêcheur and Évelyne Proust have convincingly argued that the construction of the church began between 1100 and 1115 and was completed a few decades later, and that the portal was carved about $1130-40 .^{30}$ Thus, the Cluniac period corresponded to a new, positive phase in the history of the abbey after the crises of the past. Not only was the church reconstructed during that time, but the general prosperity of the abbey is evident

26. Deloche, Cartulaire de l'abbaye, xxvii-xxviii.

27. On the expansion of Cluny at the time of Abbot Hugh, see Cantarella, I monaci di Cluny, 179-211.

28. Bernard and Bruel, Recueil des chartes de l'abbaye de Cluny, 5 (1894): 277-78, doc. 3924; for the other abbots, see Deloche, Cartulaire de l'abbaye, xxix. Galterius is mentioned in a document of 1145, Petrus de Sancto Sereno in one of 1188 (ibid., 264-65) and in another of 1204 (ibid., 71-72).

29. The last document that attests to the presence of a Cluniac abbot at Beaulieu dates to 1213. Scholars have suggested that the archbishop of Bourges opposed the abbey's connection with Cluny: Deloche, Cartulaire de l'abbaye, xxviii; and Pêcheur and Proust, "Beaulieu-sur-Dordogne," 83.

30. Pêcheur and Proust, "Beaulieu-sur-Dordogne," 89-94. from the number of donations received under the Cluniac abbot Geraldus, which surpasses that of any earlier abbacy except that of Beaulieu's first abbot, Gairulfus (r. 859-99). ${ }^{31}$

Even if the institutional link with Cluny is certain, it is still unclear whether Beaulieu adopted the liturgical customs of the great Burgundian abbey. The topic of the institutional and liturgical bonds among Cluny, its foundations, and its affiliated abbeys is extremely complex, and recent scholarship has suggested a more nuanced reading of the possible interrelations. Iogna-Prat has highlighted the difference between the Cluniacensis Ecclesia and the Cluniac "nebula," distinguishing the legal status of a monastic house institutionally dependent on Cluny from the links generated by the diffusion and acceptance of Cluniac customs or, in an even broader sense, "a certain spiritual tone." ${ }^{32}$ Such a definition takes into account the diverse institutional and/or liturgical connections between abbeys or priories and Cluny. Moreover, the adoption of the Cluniac liturgy did not necessarily imply an institutional association with Cluny, as in the case of Farfa. ${ }^{33}$ That said, an institution's link with Cluny might indeed involve the adoption of its liturgical texts. For example, a comparison between the breviary-missal of the Cluniac priory of Lewes (Cambridge, Fitzwilliam Museum, MS 369) and that of Cluny itself (later used at Saint-Victor-sur-Rhins, Loire) shows the "solidity of the Cluniac tradition" in the complete concordance of the lists of responses for the four Sundays in Lent. ${ }^{34}$

In the case of Beaulieu, the adoption of Cluniac liturgical texts should not be ruled out solely because of the absence of concrete documentary evidence. The history of the abbey

31. Beitscher, "Monastic Reform," 208-10.

32. Iogna-Prat, Order and Exclusion, 54.

33. Glauco Maria Cantarella, "È esistito un 'modello cluniacense??" in Dinamiche istituzionali delle reti monastiche e canonicali nell'Italia dei secoli X-XII: atti del XXVIII Convegno del Centro studi avellaniti, Fonte Avellana, 29-31 agosto 2006, ed. Nicolangelo D'Acunto (San Pietro in Cariano: Il Segno dei Gabrielli, 2007), 61-85.

34. Anselme Davril, "À propos d'un bréviaire manuscrit de Cluny conservé à Saint-Victor-sur-Rhins," Revue bénédictine 93, nos. 1-2 (1983): 108-22, at 122. This topic has also been investigated in relation to the liturgy of the Iberian peninsula: Manuel Pedro Ferreira, "Cluny at Fynystere: One Use, Three Fragments," in Studies in Medieval Chant and Liturgy in Honour of David Hiley, ed. Terence Bailey and László Dobszay (Budapest: Institute for Musicology, 2007), 179-228. In addition, while the Cluniac liturgy was added to, consolidated, and propagated by Cluny, this liturgy, in its fundamental characteristics, was not properly Cluniac because it had been celebrated previously in Carolingian abbeys: Giorgio Picasso, “'Usus' e 'consuetudines' cluniacensi in Italia," Aevum 57, no. 2 (1983): 215 26. See also Julian Hendrix, "La liturgie monastique avant Cluny: la contribution carolingienne," in Cluny: les moines et la société au premier âge féodal, ed. Dominique Iogna-Prat, Michel Lauwers, Florian Mazel, and Isabelle Rosé (Rennes: Presses Universitaires de Rennes, 2013), 129-36.

$60: \quad$ Gesta $\quad$ v56n1, Spring 2017 
affected the integrity of its archive and library, and the sole witness to its medieval fortunes is a relatively small cartulary transmitted in a later transcription. The situation at Beaulieu could well have been similar to that of the abbey of SaintArnoul de Crépy-en-Valois, founded in 1008 and donated to Cluny in 1078, as they shared a very similar relationship with the Burgundian abbey. Significantly, the twelfth-century lectionary of Saint-Arnoul (Paris, Bibliothèque de l'Arsenal, cod. 162) was a copy of the Cluniac Lectionary, the one produced and used at Cluny. ${ }^{35}$

When the portal of Beaulieu is examined in light of the liturgical readings of Cluny, as transmitted by the late eleventhcentury Cluniac Lectionary and other contemporary sources, it is possible not only to posit the existence of such a liturgical connection but also to explain some of the apparent inconsistencies and anomalies in its sculpted portal. A liturgical reading of the reliefs was already suggested by Jean French in 1976, but in her analysis, this line of argument is compromised by her antiheretical interpretation of the carvings. Furthermore, French's understanding of the liturgy was not linked with the chronology and functions of the site; for example, she stressed the association with baptism, which was not a prerogative of an abbey church. ${ }^{36}$ It is still problematic, however, to define the possible intended audiences for the portal. New investigations of the medieval urban layout of Beaulieu, in the area enclosed by the walls, indicate that during the twelfth century the town was not yet developed. ${ }^{37}$ Although the precise nature of the different phases of the urban development is difficult to ascertain in the absence of clear documentary evidence, the material remains of the town seem to confirm that the settlement developed only during the thirteenth century. It is therefore possible to hypothesize that during the twelfth century the abbey church, particularly if it was within the monastic enclosure, was used mainly by its religious community.

35. Étaix, "Le lectionnaire de l’office à Cluny," 92.

36. French, "Innovative Imagery" (1976), 24-25.

37. According to the survey of the settlement made by Pierre Garrigou Grandchamp, none of the houses can be dated before the thirteenth or fourteenth century, and, more generally, as pointed out by Frédéric Le Hech, the settlement itself was not developed before the thirteenth century. Garrigou Grandchamp, "Introduction à l'architecture domestique urbaine, du XIIe au milieu du XVe siècle, dans le Bas-Limousin," Congrès archéologique de France, 163rd session, 9-81, at 30-35; and Le Hech, Histoire de Beaulieu-sur-Dordogne et de son pays (Limoges: Ardents, 2010), 37-39. The development of the consulate of the town of Beaulieu, a form of self-government, corresponded to the Cluniac crisis at the abbey: Isabelle Ribiéras, "Beaulieu en Bas-Limousin du XIIIe au XVe siècle: la difficile émancipation du pouvoir consulaire," in Espaces et pouvoirs urbains dans le Massif Central et l'Aquitaine du Moyen Âge à nos jours: actes du colloque, ed. Michel Cassan and Jean-Loup Lemaitre (Ussel: Musée du Pays d'Ussel, 1994), 61-76.

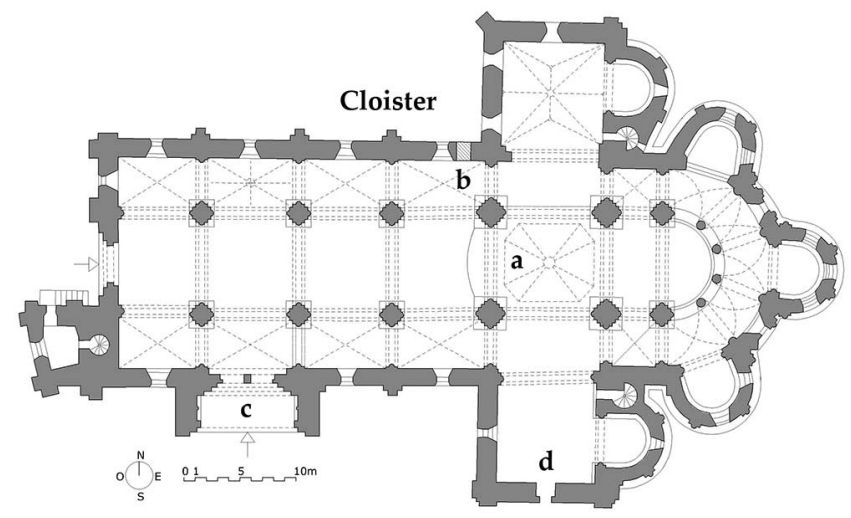

Figure 5. Abbey church of Saint-Pierre, Beaulieu-sur-Dordogne, twelfth century, plan: (a) area of the choir, (b) access to the cloister, (c) south portal, (d) access to the area south of the church (drawing: Erica Bossi).

This theory is supported by another piece of evidence: fewer than five hundred meters from the abbey church, the chapel of Notre-Dame du Port (now the Chapelle des Pénitents), dependent on the parish church of Sioniac, had been founded in the twelfth century, and the cura animarum was undertaken there for the community of the faubourg. ${ }^{38}$

\section{Performances in Stone}

The monumental portal of Beaulieu is located on the south flank of the church, corresponding to the second bay from the western end of the building (Fig. 5c). The projecting porch, which houses the majority of the sculptural program, is of notable size and scale: as large as the bay of the church (ca. $8 \mathrm{~m}$ ), its vault (reconstructed 1880-89) reaches the height of the church flank; its depth (ca. $4 \mathrm{~m}$ ) is similar to the width of the aisles in the interior of the building. The complex underwent major restorations during the nineteenth century, and the original location of some of the sculpture is still uncertain. ${ }^{39}$ The porch contains carved scenes on each of its flanks, and, on the entry wall, monumental reliefs on the jambs represent St. Peter and St. Paul (Fig. 1). These flank a multifigure trumeau that undergirds a double lintel and is dominated by the huge tympanum. The porch is an enormous kaleidoscope: its carved figures, nearly human in scale, create visual dialogues between the different scenes and with the viewer through gesture and placement. I scrutinize all these components in relation to liturgical texts and sources and ex-

38. Bernadette Barrière, Sandrine Boisset, Evelyne Proust, and Isabelle Ribiéras, Beaulieu sur Dordogne (Limoges: Presses Universitaires de Limoges, 1993), 36-37.

39. For the restorations, see note 15 above. 
plore the possible functions of the space as a site of performative liturgy.

The right side of the porch (Fig. 3) presents three scenes, whose identification is facilitated by the inscriptions on the carved tower: "Si fili(us) dei es / dic ut lapi/de(s) isti / panes fi/ant" (below) and "Si fili(us) d(e)i es / mit(t)e te / deorsum" (above). These verses are taken from the Gospel of Matthew 4:3 and 4:6, respectively: "If thou be the Son of God, command that these stones be made bread"; "If thou be the Son of God, cast thyself down." The spatial articulation of these inscriptions indicates the order of the scenes: the viewer reads the narrative starting at the bottom left, where Christ, moving toward the left, looks at the devil who is pointing at the stones; then, immediately above, Christ faces the devil atop a pinnacle of the Temple in the Holy City. To the right is the third temptation, as narrated in Matthew 4:8-9: "Again the devil took him up into a very high mountain, and shewed him all the kingdoms of the world, and the glory of them, and said to him: 'All these will I give thee, if falling down thou wilt adore me.'” The kingdoms of the world are represented here by the upper portions of two buildings carved at the feet of Christ.

Even though the narration of these events, like the biblical source, reads from left to right, the gestures of Christ and the position of his body-consistently moving or facing to the left-suggest a movement from right to left, from the exterior toward the interior of the church. At the bottom left, Christ is shown as if entering the church while walking away from the devil. While this is the first scene according to the Gospel narrative, it is the last one encountered by the viewer approaching the church and thus imitating Christ's movement. Stepping back and looking to the immediate right, the viewer encounters a modern copy of a statue now preserved inside the church. It represents a man standing on three beasts, his torso twisted toward the viewer's right, where three small angels are shown (Fig. 6). ${ }^{40} \mathrm{~A}$ long scholarly tradition has identified this figure as a representation of Psalm 90 (91): 11-13 and a type for Christ. It says, "For he hath given his angels charge over thee; to keep thee in all thy ways. In their hands they shall bear thee up; lest thou dash thy foot against a stone. Thou shalt walk upon the asp and the basilisk; and thou shalt trample under foot the lion and the dragon." ${ }^{41}$ Scholars have

40. Pêcheur and Proust, "Beaulieu-sur-Dordogne," 99-101.

41."Quoniam angelis suis mandabit de te ut custodiant te in omnibus viis tuis / in manibus portabunt te ne forte offendas ad lapidem pedem tuum / super aspidem et basiliscum ambulabis et conculcabis leonem et draconem." Translation from Douay-Rheims online edition. Christe, "Le portail de Beaulieu," 63-65 (he is not sure if the sculpture is in its original location); Klein, "Programmes eschatologiques," 333; and Franzé, “Art et réforme clunisienne," 55.

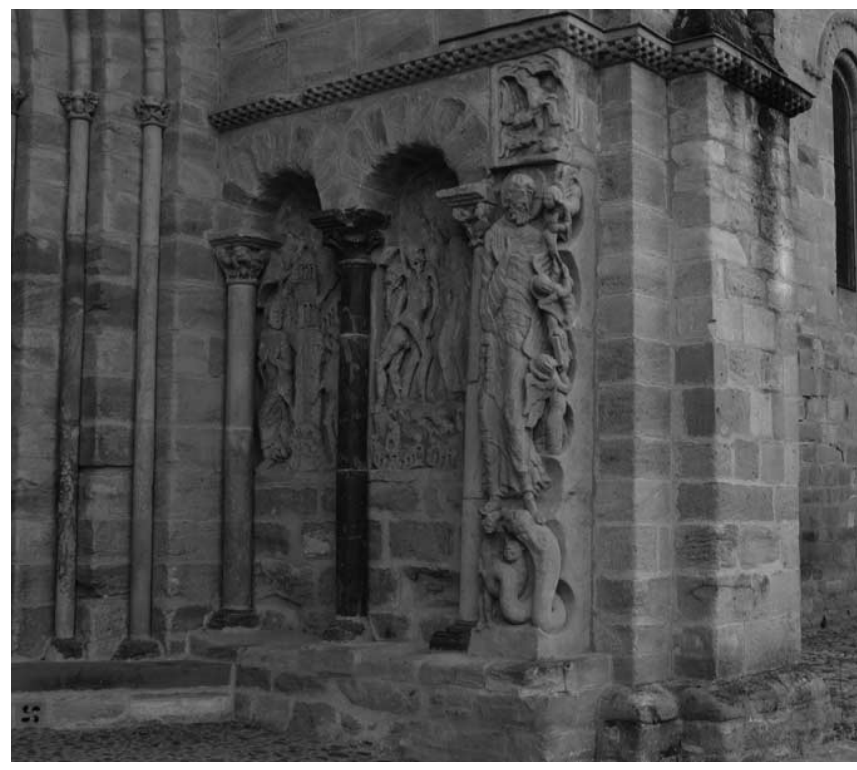

Figure 6. Christ over the beasts (modern copy, right) and the three temptations of Christ, 1130-40, right flank of the portal porch, abbey church of Saint-Pierre, Beaulieu-sur-Dordogne (photo: author). See the electronic edition of Gesta for a color version of this image.

adduced various links between this image and the adjacent temptations, noting that this psalm is recalled in the Gospel of Matthew, where it underscores the triumph of Christ over the tempter. ${ }^{42}$

A further link can be established in light of liturgical texts. The three temptations of Christ appear in the Cluniac Lectionary in the Gospel reading for the first Sunday of Lent, and the carved inscriptions point to this very connection. ${ }^{43}$ The temptation episodes are mentioned twice in the New Testament, in Matthew 4:1-12 and Luke 4:1-14. The two versions differ in some details, particularly in the succession of the temptations, and in the Vulgate they use different words. To an already easily identifiable set of scenes the planner of the Beaulieu portal added inscriptions taken from the Gospel of Matthew, specifically the passage read on the first Sunday of Lent. A liturgical reading of these reliefs is further supported by the sculpture to the right of the temptations. This carving stands out because it is the first one encountered by someone approaching the portal and it is larger than the nearby

42. Christe, "Le portail de Beaulieu," 63-65; Zink, "Moissac, Beaulieu, Charlieu," 147-48; and Klein, "Programmes eschatologiques," 333.

43. BnF, NAL 2246, fol. 29r. Jean French ("Innovative Imagery" [1972], 91-92) suggested a connection between the portal and liturgical readings (without, however, mentioning the Cluniac Lectionary), but she developed her argument in the direction of the struggle against heresy. 
scenes. Another Cluniac liturgical source connects Psalm 90 (91) with the three temptations of Christ: in the eleventhcentury Gradual (Graduale et prosarium ad usum Cluniacensem), this psalm appears on the pages devoted to the first Sunday of Lent. ${ }^{44}$ Thus, the right flank of the Beaulieu porch shows the liturgical progression of the first Sunday of Lent, and even though the temptations are represented from left to right, the depiction of the body of Christ and the sequence of psalm to Gospel suggests movement from the exterior to the interior of the church. This movement likely reflects how the space was experienced by viewers as they approached the entrance into the sacred building.

The group of sculptures on the face of the left (western) buttress of the porch further strengthens the bond between this part of the portal and the Cluniac liturgy. The reliefs in question are modern copies (undertaken during the restorations of 2001-2) of three sculptures now displayed inside the church. ${ }^{45}$ They represent the personifications of Gula (Gluttony, with an empty dish in his hands), Avaritia (Greed, with a bag of money hanging from his neck), and Luxuria (Lust, a nude female) (Figs. 1, 7). The location of these three sculptures may have been altered during the nineteenthcentury restorations, since their current arrangement is unusual: their heads face left, in the direction of the western end of the church. In addition, it seems likely that the relief of Luxuria did not originally relate to the other figures; it is slightly larger, and the corbel at her feet contains a completely different type of decoration. Nonetheless, in the Cluniac Lectionary the subject of the vices is directly linked to the Gospel recited on the first Sunday of Lent, which is followed by readings taken from a homily of Gregory the Great. ${ }^{46}$

In this homily, Gregory connects the three temptations of Christ with three vices. He explains that Gula relates to the first temptation, when Christ was asked to transform a stone into bread; Vana Gloria to the second ("If you are the Son of God, throw yourself down"); and Avaritia to the third temptation, when Christ was offered all the kingdoms of the world. ${ }^{47}$ Thus, two of the three vices cited in Gregory's hom-

44. BnF, MS lat. 1087, fol. 28v. For this manuscript, see Eduardo Henrik Aubert, "Identité, échange, transformation: genèse de la notation musicale clunisienne," in Iogna-Prat, Lauwers, Mazel, and Rosé, Cluny: les moines et la société, 145-65, at 150-51.

45. Pêcheur and Proust, "Beaulieu-sur-Dordogne," 101.

46. BnF, NAL 2246, fols. 29r-29v (eleventh and twelfth readings). The Latin text of the homilies in this article follows the wording of the Cluniac Lectionary; English translations are from Forty Gospel Homilies, trans. David Hurst (Kalamazoo, MI: Cistercian Publications, 1990), with minor variations.

47. "Sed si ipsu(m) ordine $(\mathrm{m})$ te(m)ptationis ei(us) aspicimus, pensamus quanta magnitudine nos a te(m)ptatione liberamur. . . $\mathrm{P}(\mathrm{er}) \operatorname{gula}(\mathrm{m})$ quippe te $(\mathrm{m})$ ptat qui dicit: Dic ut lapides isti panes

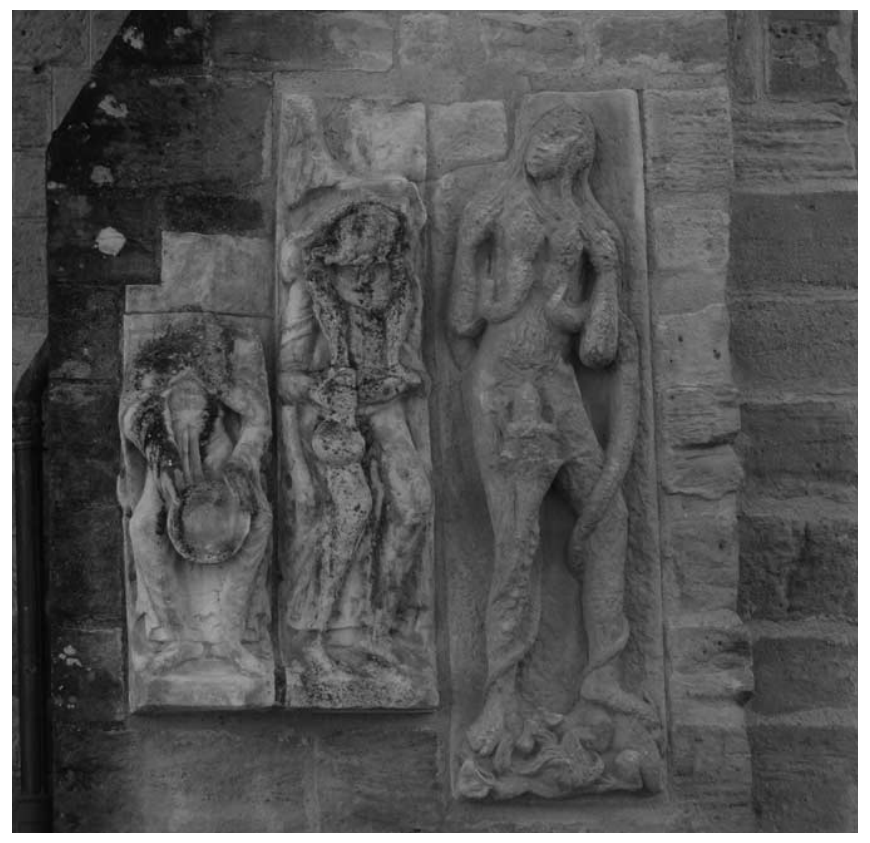

Figure 7. Personifications of Gula, Avaritia, and Luxuria (modern copies), left buttress of the portal porch, abbey church of Saint-Pierre, Beaulieu-sur-Dordogne (photo: author). See the electronic edition of Gesta for a color version of this image.

ily and read at Cluny are depicted at Beaulieu. Given the positions of their heads, it seems plausible that the figures were originally located on the front of the right (eastern) buttress of the porch; in that case, their gaze would have been directed toward Christ triumphing over the beasts, thus mirroring and reinforcing the meaning of the homily. The third personification, the nude woman, depicts Luxuria and not Vana Gloria, but considering the difference in scale and corbel decoration, she may have been intended to occupy a different location and merely replaced a lost or damaged Vana Gloria in the nineteenth century (or perhaps Luxuria was deemed more appropriate in a monastic context). ${ }^{48}$ Thus, the probable

fiant. P(er) vana(m) gl(ori)am te(m)ptat cum dicit: Si Filius D(e)i es, mitte te deorsum. $\mathrm{P}(\mathrm{er})$ sublimitatis avaritia $(\mathrm{m})$ te $(\mathrm{m})$ ptat $\mathrm{cu}(\mathrm{m})$ regna om(n)ia mundi ostendit, dicens: Haec omnia $t(\mathrm{ibi})$ dabo, si $\mathrm{p}$ (ro)cidens adoraveris me. Sed eisde $(\mathrm{m})$ modis a secundo homine vincitur, quibus $\mathrm{p}$ (ri)mum hominem se vicisse gl(ori)abatur, ut a $\mathrm{n}$ (ost)ris cordib(us) ipso aditu capt(us) exeat, quo nos aditu intromissus tenebat." Gregory the Great, Homiliae in Evangelia, 111-12; and Hurst, Forty Gospel Homilies, 102-3.

48. On the personifications of the virtues and vices, see Adolf Katzenellenbogen, Allegories of the Virtues and Vices in Mediaeval Art from Early Christian Times to the Thirteenth Century, trans. Alan J. P. Crick (New York: Norton, 1964). For the medieval definitions and conceptualizations of Vana Gloria, see Maria Giuseppina Muzzarelli, "La vanagloria fra gusto e peccato negli ultimi secoli del 
combination of scenes on the right side of the porch finds a justification in the liturgy, while the connection between the temptations of Christ and the three vices established in the Cluniac Lectionary and visualized in the portal reinforces the link between Beaulieu and Cluny.

Directly opposite the temptations of Christ, on the left side of the porch, another biblical story is represented. This one is articulated in two uneven registers (Fig. 4). In the lower one, a man with a long bifurcated beard sits among seven lions, below an arcaded structure; to the left, an angel carries another human figure, extremely damaged, toward the right. The inscription to the right of the bearded man's head, "daniel," identifies the scene as Daniel in the lions' den. As with the temptations, there are two different biblical accounts of this episode: Daniel 6:12-24 and 14:31-42. The scene at the left, however, in which the angel is carrying a person by his hair, clarifies that the carvings depict the passages narrated in book 14: while the prophet was incarcerated with seven lions, an angel took Habakkuk from Judaea "by the top of his head, and carried him by the hair of his head," to feed Daniel. $^{49}$

Two further scenes are carved in the upper register. The first, on the left, shows an architectural structure consisting of two towers surmounting three arches, with a human face in the central opening. On the right, a figure (only the lower part of the body survives) leans toward a dragon represented beneath it. These scenes appear to depict two episodes from the same book of Daniel, narrated shortly before his imprisonment in the lions' den. On the right, Daniel is killing the dragon venerated by the Babylonians (Dan. 14:23-30); on the left, the building containing the round face might be associated with the temple of the idol Bel (Dan. 14:1-22). ${ }^{50}$ But why are there three scenes devoted to Daniel at Beaulieu?

medioevo," Doctor Seraphicus: bolletino d'informazioni del Centro di studi bonaventuriani 45 (1998): 99-116.

49. Translation from Douay-Rheims online edition. Elizabeth Saxon, "Carolingian, Ottonian and Romanesque Art and the Eucharist," in A Companion to the Eucharist in the Middle Ages, ed. Ian Christopher Levy, Gary Macy, and Kristen Van Ausdall (Leiden: Brill, 2012), 251-324, at 291, stresses the "penitential-eucharistic route of salvation" present in this image.

50. The relief on the right has been interpreted as Daniel killing the dragon by the majority of scholars, with the notable exception of Elizabeth Saxon (Eucharist in Romanesque France, 239), who identifies this figure as St. Michael. The relief on the left has been interpreted by Jochen Zink ("Moissac, Beaulieu, Charlieu," 146) as Daniel looking toward Jerusalem, but it is also possible that the scene depicts the temple of Bel (Besancon, "French Romanesque Portals," 302-3; and Franzé, "Art et réforme clunisienne," 47), especially given that the face emerging from the building does not resemble that of Daniel in the lower register.
The image of Daniel between two lions was an extremely popular topos during the Middle Ages, whereas the representation of the prophet with Habakkuk taken by the angel is much less common. The latter is found, however, in the mid-eleventh-century Saint-Sever Beatus; in capitals at SaintLazare in Autun, San Pedro in Loarre, and Sant'Antimo in Tuscany; in the cloister of Moissac; in the porch of SaintGeorges in Ydes-Bourg ( $80 \mathrm{~km}$ northeast of Beaulieu); in a relief of the dismantled Romanesque south portal of the cathedral of Worms; and in an early twelfth-century Cistercian manuscript of Jerome's commentaries on Daniel, the minor prophets, and Ecclesiastes. ${ }^{51}$ At Beaulieu, however, these scenes-which adhere closely to the biblical narrative, even in the number of lions-are combined with the killing of the dragon and the probable depiction of the temple of Bel, making this one of the most expansive monumental medieval cycles of the story of Daniel..$^{52}$

The Cluniac Lectionary, which contains only the readings for Sundays and other major feasts, does not in this case provide the key to understanding the Daniel images in a liturgical context. Yet according to a later Cluniac missal, dated 1493, the text of Daniel 14:27-42 was read on the Tuesday of Passiontide (the last two weeks of Lent; Feria III)..$^{53}$ This later testimony reflects a much earlier liturgical tradition that

51. Beatus of Saint-Sever, BnF, MS lat. 8878, fol. 233v: Le "Beatus de Saint-Sever": manuscrit latin 8878 de la Bibliothèque nationale de France (Dax: Comité d'Études sur l'Histoire et l'Art de la Gascogne, 2013), 63. Autun: Denis Grivot, La sculpture du XIIe siècle de la cathédral d'Autun (Colmar: Éditions S.A.E.P., 2000), 83-84. Loarre: David L. Simon, "Daniel and Habakkuk in Aragon," Journal of the British Archaeological Association 38 (1975): 50-54. Sant'Antimo: Marco Burrini, "Il Maestro di Cabestany a Sant'Antimo," in Nuove ricerche su Sant'Antimo, ed. Adriano Peroni and Grazia Tucci (Florence: Alinea, 2008), 31-44. Moissac: Quitterie Cazes and Maurice Scellès, Le cloître de Moissac (Bordeaux: Éditions Sud Ouest, 2001), 214-15. Worms: Eduard Sebald, "Das romanische Südportal," in Das Südportal des Wormser Doms (Worms: Wernersche Verlagsgesellschaft, 1999), 11-24. Ydes-Bourg: Pierre Quarré, "Le portail de Mauriac et le porche d'Ydes: leurs rapports avec l'art du Languedoc et du Limousin," Bulletin monumental 98 (1939): 129-51. For the Cistercian manuscript and additional examples, see William J. Travis, "Daniel in the Lions' Den: Problems in the Iconography of a Cistercian Manuscript, Dijon, Bibliothèque Municipale, Ms. 132," Arte medievale, 2nd ser., 14, nos. 1-2 (2000): 49-71.

52. A similar combination of scenes can be found in the capitals of the western portal of Jaca Cathedral: Serafín Moralejo, "Pour l'interprétation iconographique du portail de l'Agneau à SaintIsidore de Léon: les signes du zodiaque," Les cahiers de Saint-Michel de Cuxa 8 (1977): 137-73. For a comparative study of Daniel iconography, see the still fundamental Rosalie B. Green, "Daniel in the Lions' Den as an Example of Romanesque Typology" (PhD diss., University of Chicago, 1948).

53. Missale Cluniacense (Cluny: Michael Wenssler, 1493), fol. LXr.

$64:$ Gesta v56n1, Spring 2017 
was spread throughout Western Christendom, as attested by the Liber comitis (a collection of liturgical readings fully developed by the end of the sixth century), which mentions, among the readings of the Feria III of Passiontide, "Lectio Danihel prophetae. In diebus illis congregati sunt Babylonii ad regem, usque de lacu leonum" (Reading from the prophet Daniel. "The Babylonians gathered together against the king" until "the den of lions"). ${ }^{54}$ The passage in the Liber comitis makes reference in its first verse to both the destruction of the idol of Bel and the killing of the dragon (cf. Dan. 14:27: "He hath destroyed Bel, he hath killed the dragon"), and it ends with Habakkuk visiting Daniel, which is precisely what is visualized in the left flank of the porch. Furthermore, for the celebrations of the same day, the eleventh-century Gradual of Cluny echoes in one of its responses the grateful words of the prophet narrated in Daniel $14 .{ }^{55}$ On both sides of the Beaulieu porch, then, the visual narration strictly follows biblical sources used in the Cluniac liturgy, including carved quotations from the Gospel of Matthew read at the beginning of Lent and unusually detailed imagery from Daniel.

All of this suggests that the carvings of the two sides of the porch are linked through their reliance on liturgical texts. ${ }^{56}$ These same sources, moreover, illuminate the complex and unusual figuration of the tympanum (Fig. 8). As noted above, the explanation of its iconography as a depiction of the Second Coming is problematic. The tympanum shares some similarities with portals that depict the Last Judgment, such as at Sainte-Foy in Conques (Fig. 9) and Saint-Denis (Fig. 10), for example in the juxtaposition of Christ and the cross, the two angels with the trumpets, and the resurrection of the dead. However, as noted recently by Marcello Angheben, the comparison between the portals of Conques and Beaulieu is based exclusively on two themes: the cross carried by two angels and the instruments of the Passion (although in Conques the lance and the nails are represented, and in Beaulieu, the nails and a precious crown, not to be mistaken for the

54. Translation from Douay-Rheims online edition. Jerome [sic], Liber comitis, sive lectionarius per circulum anni, in Hieronymi opera omnia, Patrologiae Cursus Completus: Series Latina, ed. J.-P. Migne, 221 vols. (Paris: Garnier, 1844-64) (hereafter Migne, PL) 30 (1846): col. 502. To give just one example, the same passage appears in a tenth-century lectionary from Sankt Gall for the same day (Zurich, Zentralbibliothek, MS C 77, fols. 106r-107r). For this manuscript, see Anton von Euw, St. Galler Buchkunst vom 8. bis zum Ende des 11. Jahrhunderts (St. Gallen: Klosterhof, 2008), 1:433-35. For the formation of the Liber comitis, see Thomas F. X. Noble, "Literacy and the Papal Government in Late Antiquity and the Early Middle Ages," in The Uses of Literacy in Early Mediaeval Europe, ed. Rosamond McKitterick (Cambridge: Cambridge University Press, 1992), $82-133$, at 100 .

55. BnF, MS lat. 1087, fol. 49r.

56. French, “Innovative Imagery” (1972), 89-96. crown of thorns). The differences, however, are more striking than the similarities. In Beaulieu, Christ is accompanied by the apostles, and a depiction of the damned or elect is missing, as there are only two people, one dressed and one nude, clutched by beasts in the upper part of the lintel. ${ }^{57}$ Similarities with the portal of Saint-Denis are equally superficial..$^{58}$ There the instruments of the Passion are fully displayed, and the presence of the Elders in the voussoirs reinforces and expands the central theme of the Last Judgment, which is further clarified by the inscriptions on the scrolls held in Christ's hands, which bear quotations from Matthew $25 .{ }^{59}$ In the portals at both Saint-Denis and Conques, the inscriptions clearly and directly reference Matthew 25, whereas no inscriptions are carved in the tympanum at Beaulieu, in contrast to its porch. Another difference is of greater interest: at Conques and SaintDenis, the cross behind Christ is the cross of the Crucifixion, the True Cross, in terms of scale and according to the inscriptions, but at Beaulieu a processional cross is represented (Fig. 8). ${ }^{60}$ Clearly visible under Christ's right arm is the pointed shaft beneath the cross, the distinctive feature of processional crosses that allows them to be inserted into a longer pole and carried in ritual performances or set up in multiple sacred spaces. At the center of the depicted cross is a finely carved roundel reminiscent of the space reserved for jewels or stones in medieval processional crosses.

In his recent monograph on the visual relationship between the immediate and the final judgment, Angheben stressed that the portal of Beaulieu is an exception among monumental Last Judgment images because it is the only example limited to the Parousia (Second Coming), and its visualization of hell does not have comparanda in any other portals. ${ }^{61}$ The iconographic inconsistencies and anomalies of the portal of Beaulieu-the absence of the damned and elect, the representation of a processional cross, the unusual depiction of hell-are best approached through an investigation of the portal in relation to liturgical sources. The tympanum,

57. Marcello Angheben, D’un jugement à l'autre: la représentation du jugement immédiat dans les Jugements Derniers français; 1100 1250 (Turnhout: Brepols, 2013), 190. Yves Christe, Jugements Derniers (Saint-Léger-Vauban: Zodiaque, 1999), 183-84, correctly points out that in Beaulieu there are no references to the torments of hell.

58. Gerson, "Suger as Iconographer," 188.

59. Angheben, D'un jugement à l'autre, 301-2.

60. Yves Christe was the first to suggest the idea of the triumphal cross, in Christe, "Le portail de Beaulieu," 58. For the functions and materiality of processional crosses, see César García de Castro Valdés, ed., Signum salutis: cruces de orfebrería de los siglos V al XII (Oviedo: Consejería de Cultura y Turismo del Principado de Asturias, 2008); and Cynthia Hahn, Strange Beauty: Issues in the Making and Meaning of Reliquaries, 400-circa 1204 (University Park: Pennsylvania State University Press, 2012), 73-102.

61. Angheben, D’un jugement à l’autre, 608. 


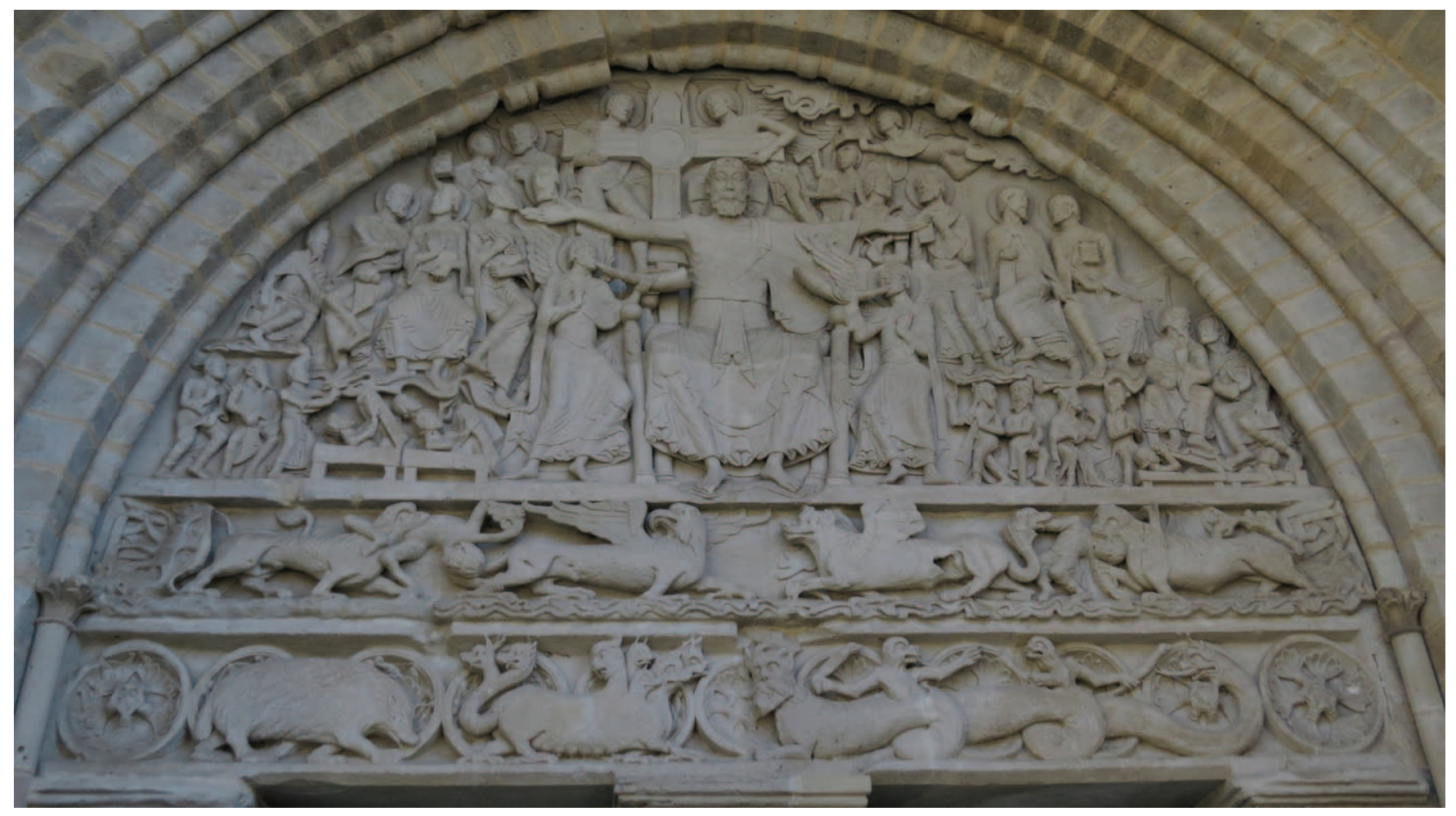

Figure 8. Tympanum, 1130-40, south portal, abbey church of Saint-Pierre, Beaulieu-sur-Dordogne (photo: author).

in fact, might be better read as a powerful vision of Christ's Resurrection, one that finds its explanation in the Cluniac liturgical readings used at Beaulieu.

Easter is the core of the liturgical year, and at Cluny it was celebrated through a long and complex liturgy: furthermore, the text read on this feast marked not only Christ's Resurrection but also his triumph. ${ }^{62}$ In the Cluniac Lectionary, the readings for Easter are dominated by two homilies of Gregory the Great, who praises the feast as "the solemnity of solemnities." He explains that, through the Resurrection,

The Lord fulfilled what he said before his passion, If I am lifted up from the earth, I shall draw all things to myself. He who left none of his elect in the lower world did indeed draw all things to himself. He took from them all the predestinate. The Lord by his rising did not restore to pardon any unbelievers, or those whose wickedness had caused them to be given over to eternal punishment; he snatched away from the confines of the

62. On Easter celebrations at Cluny, see Michel Huglo, "L'office du Dimanche de Pâques à Cluny au Moyen Âge," in From Dead of Night to End of Day: The Medieval Customs of Cluny, ed. Susan Boynton and Isabelle Cochelin (Turnhout: Brepols, 2005), 153-62. lower world those whom he recognized as his own as a result of their faith and deeds. ${ }^{63}$

Having established a connection between Christ's Resurrection and the destiny of those confined in the "lower world," Gregory draws on the prophecy of Hosea (13:14), "O death, I will be thy death; O hell, I will be thy bite." He explains that

63. BnF, NAL 2246, fol. 47v: "H(anc) eni(m) recte nobilitatem solempnitatis $\operatorname{dica}(\mathrm{m})$, quia solle $(\mathrm{m})$ pnitates $\mathrm{c}(\mathrm{a})$ eteras antecedit. Sicut eni(m) in sacro eloquio $s($ an $) c(t)$ a $s($ an $) c(t) o r(u m)$, ut Cantica canticor(um), $\mathrm{p}$ (ro) sui magnitudine dicuntur, ita haec festivitas recte dici potest solle(m)nitas solle(m)pnitatum. Ex hac quippe solle $(\mathrm{m})$ pnitate exemplu(m) nobis resurrectionis datum e(st), spes caelestis patri(a)e aperta, et facta sup(er)ni regni jam p(rae) sumptibilis gl(ori)a. Per hanc electi, qui quamvis in tranquillitatis sinu, tamen apud inferni claustra tenebantur, ad paradisi am(o)ena reducti sunt. Quod ante passionem dixit, in resurrectione sua $\mathrm{D}(\mathrm{omi}) \mathrm{n}(\mathrm{u}) \mathrm{s}$ implevit: Si exaltatus fuero, a terra, om(n)ia traham ad me. Omnia etenim trax(it), qui de electis suis apud inferos nullu(m) reliquit. Omnia abstulit, utiq(ue) electa. Neq(ue) etenim infideles quosq(ue), et $\mathrm{p}$ (ro) suis criminibus eternis suppliciis deditos, ad veniam $\mathrm{D}(\mathrm{omi}) \mathrm{n}(\mathrm{u}) \mathrm{s}$ resurgendo reparavit; sed illos ex inferni claustris rapuit, quos suos in fide et actibus recognovit." Gregory the Great, Homiliae in Evangelia, 185; and Hurst, Forty Gospel Homilies, 168. 


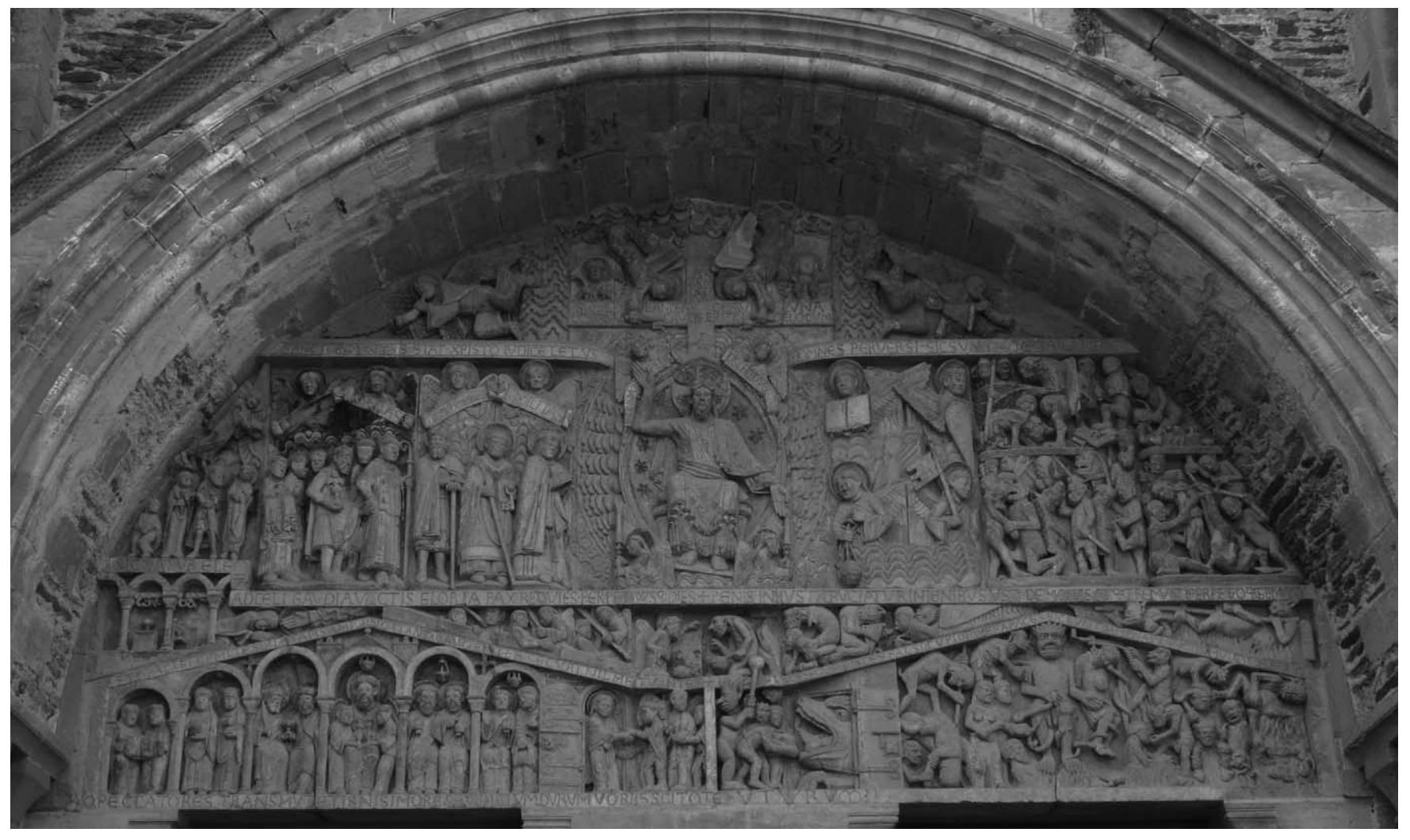

Figure 9. Last Judgment, beginning of the twelfth century, tympanum of the west portal, Sainte-Foy, Conques (photo: author). See the electronic edition of Gesta for a color version of this image.

Christ, "because he completely slayed death in his chosen people, he became death for death; but because he took away a portion of hell, and left part of it, he did not completely slay it but took a bite from it." According to Gregory, the solemnity of Easter "has broken the lower world, and opened for us the gates of the heavenly kingdom." ${ }^{64}$

This text is echoed in the portal. Gregory comments on the words of Hosea, and this could be the key to identifying the figure in the upper left part of the lunette (Fig. 11), who cannot be one of the apostles because he is smaller in scale

64. BnF, NAL 2246, fols. 47v-48r: "Unde recte etiam per Osee dicit: Ero mors tua, o mors; morsus tuus ero, inferne. Id namq(ue) q(uo)d occidimus, agimus ut penit(us) non sit. Ex eo enim quod mordem(us), parte(m) abstrahimus, parte(m)q(ue) relinquimus. Quia ergo in electis suis funditus occidit morte(m), mors mortis exstitit. Quia v(ero) ex inferno parte $(\mathrm{m})$ abstulit et parte $(\mathrm{m})$ reliquit, $\mathrm{n}$ (on) occidit funditus, sed momordit infernu(m). Ait (er)g(o): Ero mors tua, o mors. Ac si ap(er)te dicat: Quia in electis meis te funditus perimo, ero mors tua; ero morsus tuus, inferne, quia sublatis eis, te ex parte transfigo. Quae est (er)g(o) ista sole(m)pnitas quae inferni claustra destruxit, et januas nobis regni coelestis aperuit." Gregory the Great, Homiliae in Evangelia, 185-86. Translation of Hosea from Douay-Rheims online edition. and unnimbed. ${ }^{65}$ While the apostles wear tunics, this figure wears trousers, a mantle, and a pointed hat, and he has a long, forked beard. With the exception of the hat, all these features have counterparts in the depiction of Daniel on the left flank of the porch. Because their dress is very similar and they both have a forked beard, this figure, too, might represent an Old Testament character, possibly Hosea. Moreover, the vision of Hosea in the homily might also explain the unusual iconography of hell in the Beaulieu lintel. ${ }^{66}$

In the upper lintel (Fig. 8), four beasts who emerge from the mouth of hell, on the left, are clutching two men, possibly alluding to the unbelievers and sinners mentioned in

65. This figure has usually been interpreted as either a prophet or a pagan priest. See, e.g., Besancon, "French Romanesque Portals," 256; and Zink, "Moissac, Beaulieu, Charlieu," 136.

66. Barbara Franzé (“Art et réforme clunisienne," 29-33) recently suggested identifying this figure as St. Paul. However, both the beard and the dress relate to the image of Daniel in the porch. Furthermore, the depiction of St. Paul with a Phrygian cap, "signe distinctif non équivoque de ses origines juives" (ibid., 33), would constitute an iconographic rarity. On the right jamb, in fact, St. Paul is represented without the cap and with a multipart beard that does not resemble that of the figure in the lunette. 


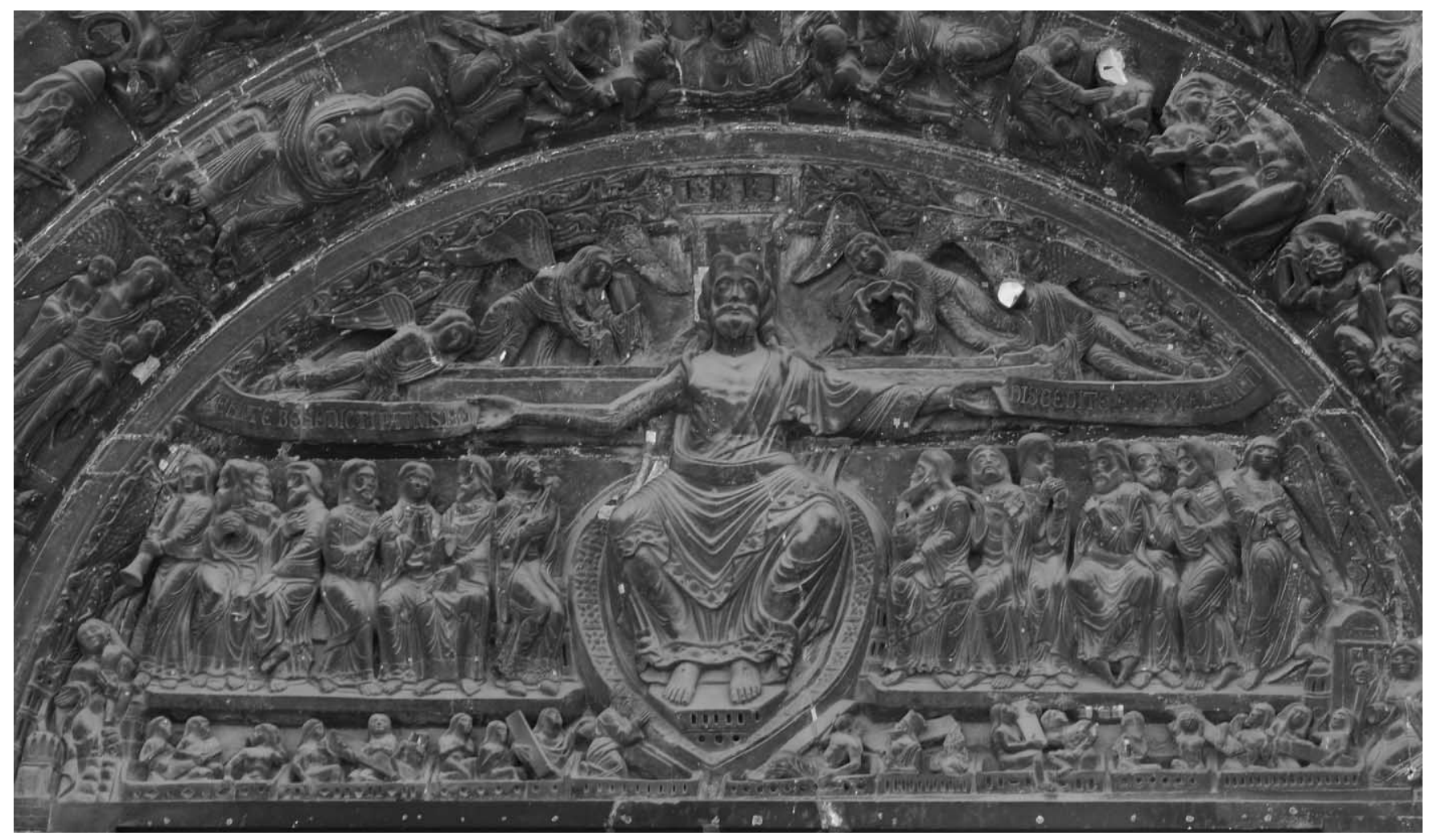

Figure 10. Last Judgment, before 1140, tympanum of the central west portal, Saint-Denis, Paris (photo: author). See the electronic edition of Gesta for a color version of this image.

Gregory's text. Only these individuals are depicted as suffering and in pain: their faces are distorted, and they show their teeth (Fig. 12). The four beasts are accompanied by another three monsters in the lower lintel, including a dragon with seven heads. The vision of Hosea about the destruction of the gates of hell might also be evoked by the pose of Christ: while the other figures stand above the borderline separating hell in the architrave from the scenes in the lunette, Christ's feet interrupt this division, as if he were forcibly entering the lower scene.

The vision of hell is further connected to the resurrection of the dead, visualized in the tympanum at the feet of the apostles (Figs. 2, 11). This echoes a homily of Gregory the Great, the twelfth reading for Easter in the Cluniac Lectionary. Here the author explains that there are two lives, one mortal, the other immortal; the first ends in death, the second in resurrection. Then follows:

But the mediator between God and men, Christ Jesus, came. He took upon himself the one, and revealed to us the other; the one he bore by dying, and the other he revealed by rising. If he had promised resurrection of the body to us who knew this mortal life, but did not visibly manifest it, who would have believed his promises? ... To instruct us then in our ignorance, and to strengthen our weakness, he decided that the example of his own resurrection should not be unique. $\mathrm{He}$ alone died at that time, and yet he was not the only one who rose for it is written that: Many bodies of saints who had fallen asleep arose. . . To prevent our saying that no one should expect in his own case what the Godman showed in his body, we see that human beings rose together with God; and we do not doubt that they were truly human beings. ${ }^{67}$

67. BnF, NAL 2246, fols. 51r-51v: "Duae eteni(m) vit(a)e erant, quaru $(\mathrm{m})$ una $(\mathrm{m})$ noveramus, altera $(\mathrm{m})$ nesciebamus. Una quippe mortalis e(st), alia immortalis. Una corruptionis, alia incorruptionis; una mortis, alia resurrectionis. Sed venit mediator $\mathrm{D}(\mathrm{e}) \mathrm{i}$ et hominu(m) homo Christus Ih(e)s(us), suscepit una(m), et ostendit altera $(\mathrm{m})$. Una $(\mathrm{m}) \mathrm{p}(\mathrm{er})$ tulit moriendo, ostendit altera $(\mathrm{m})$ resurgendo. Si igitur nobis mortalem vita(m) ferentib(us) resurrectionem $\mathrm{p}$ (ro)mitteret carnis, et tamen hanc visibilit(er) non exhiberet, quis eius p(ro)missionib(us) crederet? ... Ad instruenda(m) (er)$\mathrm{g}(\mathrm{o})$ ignorantia $(\mathrm{m}) \mathrm{n}(\mathrm{ost}) \mathrm{ram}$, ad roborandam infirmitate $(\mathrm{m}) \mathrm{n}$ (ost)$\mathrm{ram}, \mathrm{su}(\mathrm{a})$ e resurrectionis exemplu(m) nob(is) sufficere noluit. Solus illo tempore mortuus e(st), et tamen solus minime surrexit. Nam scriptu(m) est: Multa corpora s(an)c(t)or(um) qui dormierant surrexer(unt). Ablata ergo sunt om(n)ia argumenta $\mathrm{p}(\mathrm{er})$ fidi(a)e. 


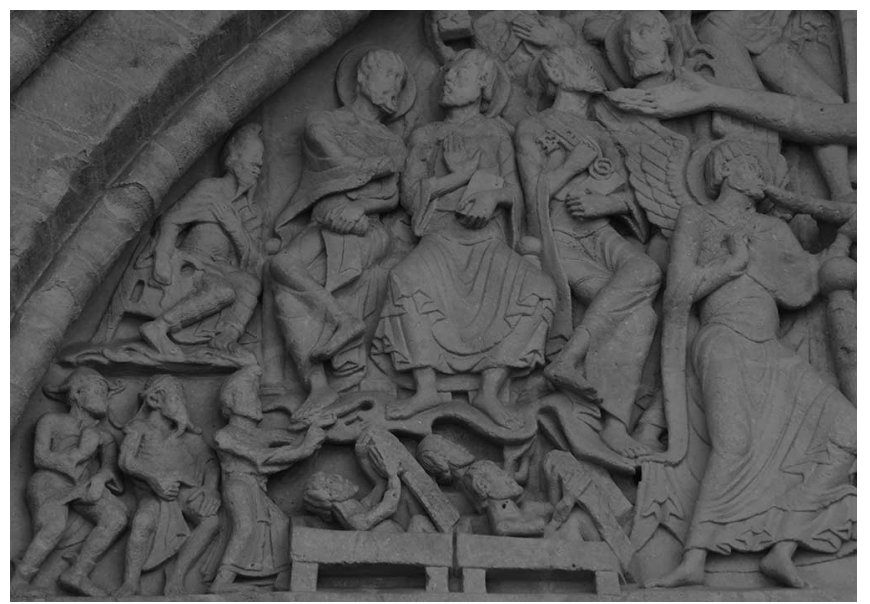

Figure 11. Left half of the tympanum, 1130-40, south portal, abbey church of Saint-Pierre, Beaulieu-sur-Dordogne (photo: author). See the electronic edition of Gesta for a color version of this image.

In this passage, Gregory unites the Resurrection of Christ with the bodily resurrection of humankind. A similar association is made in the tympanum, where, at the feet of the apostles, people are shown emerging from their sepulchers. It is worth emphasizing that these rising figures do not display any observable fear or anguish, as we witness, for example, in the portals of Saint-Denis (Fig. 10) and Autun (Fig. 13). Instead, four of the five figures (three on the left, one on the right) gaze peacefully at Christ while removing the decorated lids of their coffins.

Next to these resurrection vignettes, seven small people are represented at a scale less than half that of the apostles. Some wear pointed caps; four of them gesture to Christ and the apostles in the tympanum, while the other three lift their tunics (Figs. 2, 11). As Henry Kraus convincingly argued in 1965, the peaked caps and the gestures signal their identification as Jews who, through the act of lifting their tunics, refer to their circumcision. ${ }^{68}$ At least two of them have a forked beard analogous to that of Daniel in the porch and the seated figure at the left edge in the tympanum, here identified as Hosea (Figs. 4, 11).

The presence of the Jews in the portal has been the focal point of many investigations that read these images and the majority of the portal in relation to the writings of Peter the Venerable, stressing the negative connotations of these fig-

Ne quis enim dicat: Sperare de se non debet homo quod in carne sua exhibuit homo $\mathrm{D}(\mathrm{eu}) \mathrm{s}$, ecce cum $\mathrm{D}(\mathrm{e})$ o homines resurrexisse cognoscim(us), et quos puros fuisse homines n(on) dubitamus." Gregory the Great, Homiliae in Evangelia, 177-78; and Hurst, Forty Gospel Homilies, 161.

68. Kraus, "Reinterpretation of the 'Risen Dead." ures. This interpretive strand has also been expanded to identify those who accompany the tunic-lifting Jews as Saracens or, more generally, as heretics. ${ }^{69}$ Yet these figures, and the ones rising from their sepulchers, do not resemble the damned represented at Autun, for example, who look lost in their anguish (Fig. 13), or at Conques, unable to control their bodies (Fig. 9). ${ }^{70}$ Their expressions and gestures do not suggest pain or desperation. On the contrary, some of them point at Christ, just as many of the apostles do, and the last one on the right has joined his hands in front of his chest (Fig. 14). Such iconography is not usually connected with the damned but rather with the act of praying, such as that of Peter and Paul in the capital of the avant-nef of Vézelay or the figures of the elect, next to Christ, in the portal at Autun (Fig. 13). ${ }^{71}$

The visual evidence therefore suggests an alternative interpretation of these small figures. The depiction of the Jews at Beaulieu finds justification in another homily of Gregory the Great, the twelfth reading for Easter in the Cluniac Lectionary:

There comes now to mind what the Jews said derisively of the crucified Son of God: If he is the king of Israel, let him come down from the cross, and we will believe in

69. Debra Higgs Strickland, Saracens, Demons and Jews: Making Monsters in Medieval Art (Princeton: Princeton University Press, 2003), 160-61; Silke Büttner, Die Körper verweben: Sinnproduktion in der französischen Bildhauerei des 12. Jahrhunderts (Bielefeld: Transcript, 2010), 215-25; and Besancon, "French Romanesque Portals," 277-87.

70. Saint-Lazare in Autun: Willibald Sauerländer, "Über die Komposition des Weltgerichts-Tympanons in Autun," Zeitschrift für Kunstgeschichte 29, no. 4 (1966): 261-94; Jochen Zink, "Zur Ikonographie der Portalskulptur der Kathedrale Saint-Lazare in Autun," Jahrbuch des Zentralinstituts für Kunstgeschichte 5-6 (1989-90): 7-160; and Don Denny, "The Last Judgment Tympanum at Autun: Its Sources and Meaning," Speculum 57, no. 3 (1982): 532-47. Sainte-Foy in Conques: Éliane Vergnolle, Henri Pradalier, and Nelly Pousthomis, "Conques, Sainte-Foy: l'abbatiale romane," in Congrès archéologique de France, 167th session, 2009, monuments de l'Aveyron (Paris: Société Française d'Archéologie, 2011), 71-160, at 134-38; and Kirk Ambrose, "Attunement to the Damned of the Conques Tympanum," Gesta 50, no. 1 (2011): 1-17.

71. Peter Klein ("Programmes eschatologiques," 332) already recognized one of the pagans in the act of praying, but he interpreted this scene as "people of the earth" awaiting the final judgment. See also Franzé, "Art et réforme clunisienne," 25-28. For the capital of Vézelay (avant-nef 9), see Marcello Angheben, "Le programme iconographique du rez-du-chaussée de l'avant-nef de Vézelay: chapiteaux et portails," in Avant-nefs et espaces d'accueil dans l'église: entre le IVe et le XIIe siècle, ed. Christian Sapin (Paris: CTHS, 2002), 45063, at 459; and Peter Diemer, "Stil und Ikonographie der Kapitelle von Ste.-Madeleine, Vézelay" (PhD diss., Universität Heidelberg, 1975), 391-99. For Saint-Lazare in Autun, see note 70 above; and Linda Seidel, Legends in Limestone: Lazarus, Gislebertus, and the Cathedral of Autun (Chicago: University of Chicago Press, 1999). 


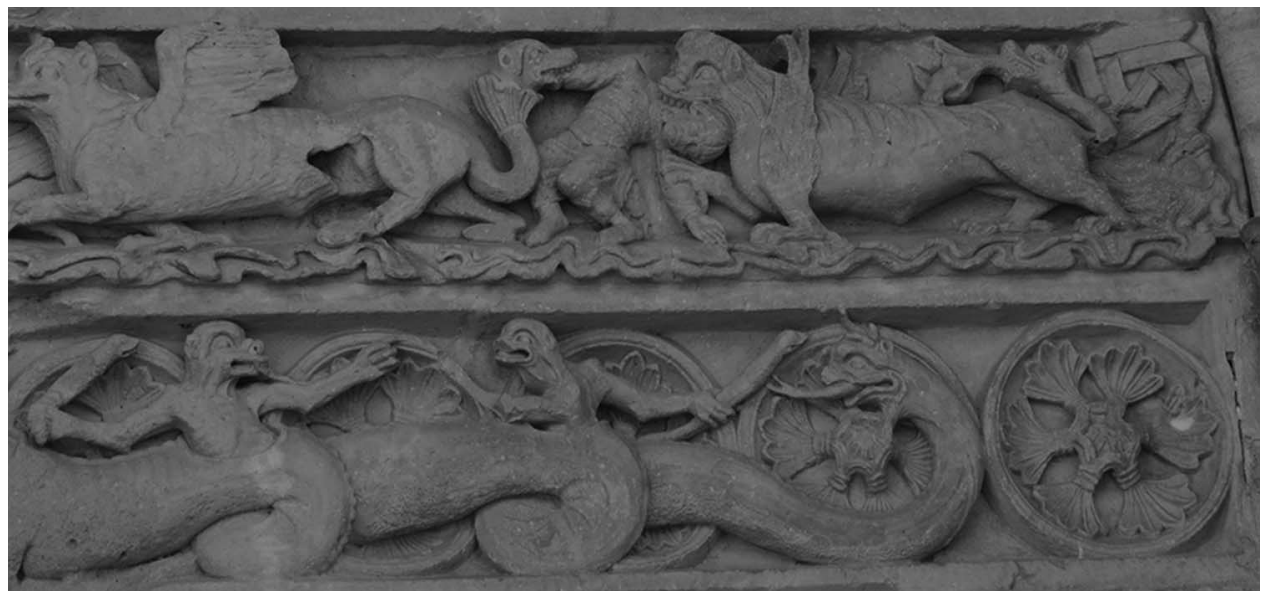

Figure 12. Vision of hell, detail of the south portal lintel, 1130-40, abbey church of Saint-Pierre, Beaulieu-sur-Dordogne (photo: author). See the electronic edition of Gesta for a color version of this image.

him. If he had then come down from the cross, yielding to their derision, he would not have showed to us the virtue of patience. Instead he waited for a while,... and he who was unwilling to come down from the cross rose from the sepulchre. It was a greater thing to rise from the sepulchre than to come down from the cross, a greater thing to destroy death by rising than to preserve life by coming down. When the Jews beheld him not coming down from the cross at their derisive remarks, when they saw him dying, they believed that they had prevailed, and rejoiced that they had consigned his name to oblivion. But see how his name, which the unbelieving multitude believed it had consigned to oblivion as a result of his death, increased throughout the world, how the multitude which rejoiced over his killing grieved over his death. They perceived that through his suffering he had arrived at glory. ${ }^{72}$

72. BnF, MS NAL 2246, fol. 51v: "Ecce vero ad memoria(m) rediit q(uo)d crucifixo D(e)i Filio Jud(a)ei insultantes dicebant: Si filius $\mathrm{D}(\mathrm{e}) \mathrm{i}$ e(st), descendat de cruce, et credimus ei. Qui si tunc de cruce descenderet, nimiru(m) insultantib(us) cedens, virtute(m) nob(is) patientia(e) non demonstraret. Sed exspectavit paululum, ...; et qui de cruce descendere noluit, de sepulchro surrex(it). Plus igitur fuit mortem surgendo destruere qua $(\mathrm{m})$ vitam descendendo servare. Sed $\mathrm{cu}(\mathrm{m})$ Judaei hunc ad insultationes suas de cruce descendere minime cernerent, $\mathrm{cu}(\mathrm{m})$ moriente $(\mathrm{m})$ viderent, $\mathrm{eu}(\mathrm{m})$ se vicisse credider(unt), nomen illius se quasi exstinxisse gavisi sunt. Sed ecce de morte nomen ei(us) p(er) mundu(m) crevit, ex qua hoc infidelis turba exstinxisse se credidit; et que $(\mathrm{m})$ gaudebat occisum, dolet mortuum, quia hunc ad suam gl(ori)am cognoscit $\mathrm{p}$ (er)venisse per $\mathrm{p}(\mathrm{o}) \mathrm{ena}(\mathrm{m})$." Gregory the Great, Homiliae in Evangelia, 178; and Hurst, Forty Gospel Homilies, 161-62.
In this homily, Gregory offers a fresh-and, to some extent, unusual-perspective: the Jews recognized that through his suffering Christ achieved glory. The concept does not occur only in this particular reading, however; it was just one part of the liturgy, which consisted of chants, antiphons, and processions, all attested in the Cluniac customaries. ${ }^{73}$ At Cluny itself, a solemn procession was performed during the celebrations of Easter with an important station in front of the church's main portal, before continuing toward the main altar. According to the Liber tramitis, the eleventh-century collection of Cluniac customs recorded for the abbey of Farfa, as the procession moved through the main portal it was accompanied by the antiphon "Christus resurgens," the second part of which sheds new light on the depiction of the Jews at Beaulieu:

Christ, rising from the dead, dies no more; death has no more dominion over him.

For in that he died, he died to sin once, but in that he lives, he lives for God.

73. On the Cluniac customaries and their reception, see, among recent publications, Anselme Davril, "Coutumiers directifs et coutumiers descriptifs d'Ulrich à Bernard de Cluny” (23-28); Isabelle Cochelin, "Évolution des coutumiers monastiques dessinée à partir de l'étude de Bernard" (29-66); and Susan Boynton, "The Customaries of Bernard and Ulrich as Liturgical Sources" (109-30), all in Boynton and Cochelin, From Dead of Night to End of Day; Riccardo Cristiani, "Le Consuetudini di Cluny: metodi, linguaggi, percorsi storiografici," I quaderni del M.Æ.S. 6 (2003): 187-98; Cantarella, "Е esistito un 'modello cluniacense'?"; and the essays in Carolyn Marino Malone and Clark Maines, eds., Consuetudines et Regulae: Sources for Monastic Life in the Middle Ages and the Early Modern Period (Turnhout: Brepols, 2014). 


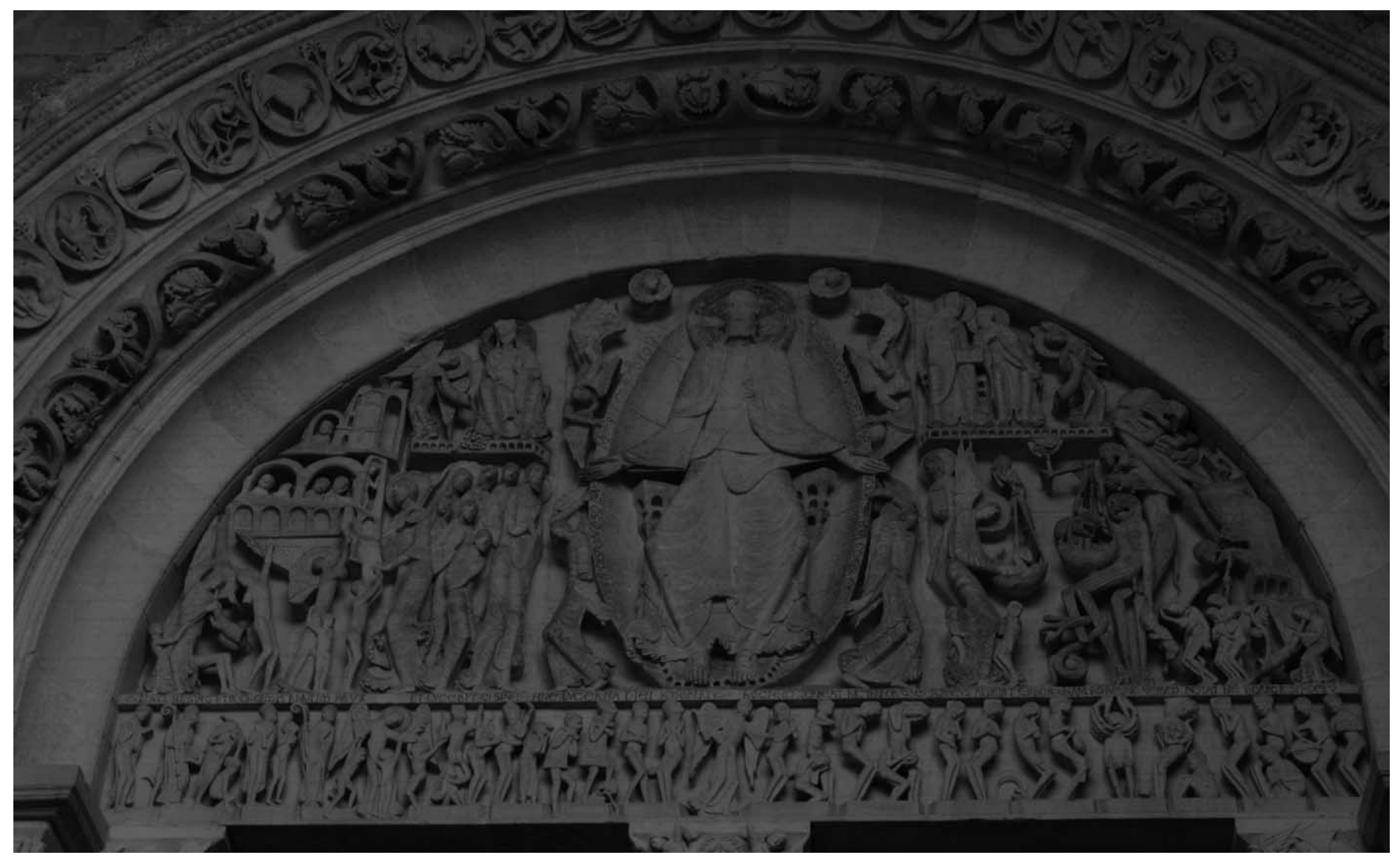

Figure 13. Last Judgment, ca. 1120-40, tympanum of the west portal, Saint-Lazare, Autun (photo: author). See the electronic edition of Gesta for a color version of this image.

He died once for our sins and rose again for our justification.

In that he lives, he lives to God. Alleluia.

Now let the Jews say how the soldiers guarding the sepulcher lost the King.

Why, in laying down the stone [of the tomb] did they not keep the rock of justice?

Either they return the buried, or they worship the resurrected, saying with us: Alleluia. ${ }^{74}$

74. "Christus resurgens ex mortuis, jam non moritur, mors illi ultra non dominabitur. / Quod enim mortuus est peccato, mortuus est semel, quod autem vivit Deo, Alleluia. / Mortuus est enim propter delicta nostra: et resurrexit propter justificationem nostram, / Quod autem vivit Deo, Alleluia. / Dicant nunc Iudaei quomodo milites custodientes sepulcrum perdiderunt Regem. / Ad lapidis positionem quare non servabant petram iustitiae? / Aut sepultum reddant, aut resurgentem adorent, nobiscum dicentes: / Alleluia." For this antiphon, see Giacomo Baroffio and Eun Ju Kim, "Proposte liturgico-musicali occidentali di testi patristici latini e greci," in Leggere i Padri tra passato e presente, ed. Mariarosa Cortesi (Florence: SISMEL-Edizioni del Galluzzo, 2010), 65-126, at 114-17; Peter Jeffery, "The Earliest Oktōēchoi: The Role of Jerusalem and Palestine in the Beginnings of Modal Ordering," in The Study of Medieval Chant:
This sequence, and in particular the last verse, goes beyond the concept of the Jews recognizing the triumph of Christ. Here they are explicitly invited to worship Christ, and this idea resonates with the Beaulieu tympanum, perhaps the very threshold before which the antiphon was sung: the Jews do not show pain, anguish, or desperation; rather, they point at Christ or the apostles, and one is shown in prayer.

Another reading from the Cluniac Lectionary, the third lecture for Saturday in Albis (after Easter), is again taken from a homily of Gregory the Great and deals with similar theological issues: the relationships between Jews and Christians, the Synagogue and the Church. In commenting on the discovery of the empty tomb of Christ after his Resurrection, Gregory

Paths and Bridges, East and West; In Honor of Kenneth Levy, ed. Peter Jeffery (Woodbridge: Boydell, 2001), 147-210, at 206; and Liber tramitis aevi Odilonis abbatis, Corpus Consuetudinum Monasticarum (hereafter CCM) 10, ed. Peter Dinter (Siegburg: Schmitt, 1980), 90. The antiphon "Christus resurgens" is also attested in other Cluniac customaries: Kristina Krüger, "Monastic Customs and Liturgy in the Light of the Architectural Evidence: A Case Study on Processions (Eleventh-Twelfth Centuries)," in Boynton and Cochelin, From Dead of Night to End of Day, 191-220, at 206-9. 


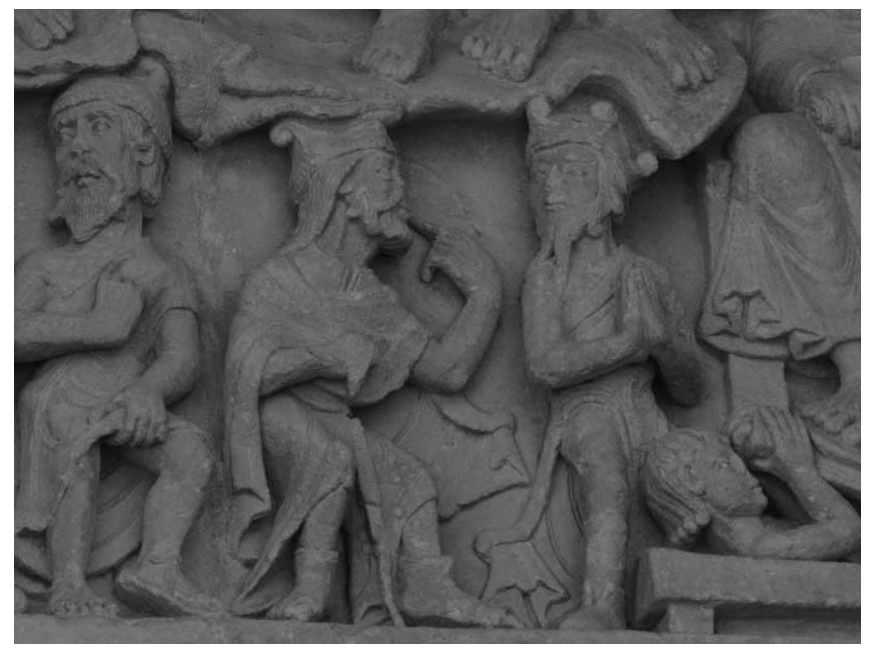

Figure 14. Figures at the feet of the apostles, detail of the right half of the tympanum, 1130-40, south portal, abbey church of Saint-Pierre, Beaulieu-sur-Dordogne (photo: author). See the electronic edition of Gesta for a color version of this image.

observes that the apostles John and Peter ran together but John arrived first, without entering the sepulcher:

What does John signify, then, if not the synagogue, and Peter, if not the Church? We shouldn't be surprised to find the synagogue said to be signified by the younger apostle, and the Church by the elder, because although the synagogue was earlier than the Church of the Gentiles in worshipping God, still by the world's reckoning the multitude of Gentiles existed prior to the synagogue. . . . They both ran together, because from the time of their beginnings right up to the end the Gentiles ran forward with the synagogue at the same pace and by a shared route, though not with the same shared understanding. ${ }^{75}$

The liturgical readings and chants discussed here present highly nuanced interpretations of the relations between Christians and Jews. In the last quotation in particular, Gregory

75. BnF, NAL 2246, fols. 55v-56r: "Quid ergo p(er) Joh(anne)m nisi Synagoga, quid per Petru(m) nisi Eccl(esi)a designat(ur)? Nec miru(m) e(ss)e videatur q(uo)d p(er) juniorem Synagoga, p(er) seniore $(\mathrm{m})$ vero $\operatorname{Eccl}(\mathrm{esi})$ a signari $\mathrm{p}(\mathrm{er})$ hibetur, quia etsi ad $\mathrm{D}(\mathrm{e}) \mathrm{i}$ cultu(m) prior e(st) Synagoga qua(m) Eccl(esi)a gentium, ad usum tam(en) s(ae)c(u)li prior e(st) multitudo gentiu(m) qua(m) Synagoga. . . Cucurrerunt ambo simul, quia, ab ort(us) sui tempore usq(ue) ad occasum, pari et co(m)muni via, etsi non pari et $\mathrm{co}(\mathrm{m})$ muni sensu, gentilitas cum Synagoga decucurrit." Gregory the Great, Homiliae in Evangelia, 182; and Hurst, Forty Gospel Homilies, 165-66. states that the Church of the Gentiles ran with the Synagogue by a "shared route, though not with the same shared understanding." This idea is further echoed in the oration Pro Iudaeis, recited at Cluny on Holy Friday, as attested by the Liber tramitis: "ut Deus et Dominus noster auferat velamen de cordibus eorum; ut et ipsi agnoscant Iesum Christum Dominum nostrum" ([Let us also pray for the Jews:] that our God and Lord may illuminate their hearts, that they acknowledge that Jesus Christ is the Savior). As noted by Bernhard Blumenkranz, the prayer itself, which obviously was not recited exclusively at Cluny, does not involve any anti-Jewish statement. ${ }^{76}$ The depiction at Beaulieu should be viewed in this light, not as a reflection of medieval antiJewish iconographies and texts, as has been suggested, ${ }^{77}$ but within an eschatological framework of redemption. This idea was also expressed by Pope Alexander II when, writing to the bishops of Spain and France in 1063, he asked them to protect the Jews, "those whom divine piety predestined for salvation." ${ }^{38}$

The attitude toward the Jews expressed visually in the portal of Beaulieu finds similarities in the reconciliatory image of the Synagogue in the Gospel of Henry the Lion of Saxony (d. 1195), in the inclusion of depictions of Jews in German Gothic screens, or in the idea of Iudaeus sacer in the Cantigas de Santa María. ${ }^{79}$ It is more problematic, however, to define

76. Dinter, Liber tramitis, 80; Bernhard Blumenkranz, Juifs et Chrétiens dans le monde occidental, 430-1096 (Louvain: Peeters, 2006), 92; and John M. Oesterreicher, "Pro Perfidis Judaeis," Theological Studies 8, no. 1 (1947): 80-96.

77. Besancon, "French Romanesque Portals," 277. On medieval Christian attitudes toward Jews, see Blumenkranz, Juifs et Chrétiens; Jeremy Cohen, ed., From Witness to Witchcraft: Jews and Judaism in Medieval Christian Thought (Wiesbaden: Harrassowitz, 1996); Giuseppe Laras, Le dispute giudaico-cristiane nel Medioevo (Milan: CUEM, 2000); and Robert Chazan, The Jews of Medieval Western Christendom, 1000-1500 (Cambridge: Cambridge University Press, 2006). For visual depictions, see, e.g., Sara Lipton, Images of Intolerance: The Representation of Jews and Judaism in the Bible moralisée (Berkeley: University of California Press, 1999); eadem, Dark Mirror: The Medieval Origins of Anti-Jewish Iconography (New York: Metropolitan Books/Henry Holt, 2014); Strickland, Saracens, Demons and Jews; Irven M. Resnick, Marks of Distinction: Christian Perceptions of Jews in the High Middle Ages (Washington, DC: Catholic University of America Press, 2012); Mitchell B. Merback, ed., Beyond the Yellow Badge: Anti-Judaism and Antisemitism in Medieval and Early Modern Visual Culture (Leiden: Brill, 2008); and Herbert L. Kessler and David Nirenberg, eds., Judaism and Christian Art: Aesthetic Anxieties from the Catacombs to Colonialism (Philadelphia: University of Pennsylvania Press, 2011).

78. Quoted in Blumenkranz, Juifs et Chrétiens, 153.

79. Elisabeth Monroe, "Fair and Friendly, Sweet and Beautiful': Hopes for Jewish Conversion in Synagoga's Song of Songs Imagery," in Merback, Beyond the Yellow Badge, 33-61; Jacqueline E. Jung, The Gothic Screen: Space, Sculpture, and Community in the Cathedrals of 
the small figures who do not point at their circumcisions. Following what is suggested in the "Christus resurgens" antiphon, and comparing them with the lintel of the main portal at Vézelay, they can perhaps be identified as Roman pagans. ${ }^{80}$

A further text suggests that the eschatological theme related to the Jews is not limited to the tympanum but may be relevant to the entire portal program at Beaulieu. An anonymous twelfth-century biblical commentary, Distinctiones (mistakenly associated with Hrabanus Maurus), draws a clear parallel between the prophet Habakkuk-cited in Daniel 14 and depicted on the porch's left flank-and Christ. As Habakkuk was in Judaea, so Christ was sent to the Jews; as Habakkuk was taken by an angel to Daniel, so Christ preached for the salvation of the Jews; and, finally, as Habakkuk was taken back whence he came by the angel, so Christ, at the end of time, will return to the Jews, and all Israel will be saved. ${ }^{81}$ While this text cannot be connected specifically to the Beaulieu portal, it reveals ideas and associations that were circulating at the time of its conception and execution.

France and Germany, ca. 1200-1400 (New York: Cambridge University Press, 2013), 147-69; and Francisco Prado-Vilar, "Iudeus sacer: Life, Law and Identity in the 'State of Exception' called 'Marian Miracle,'” in Kessler and Nirenberg, Judaism and Christian Art, 115-42.

80. Emma Simi Varanelli, “'Diversi, non adversi': l'interpretazione del timpano della Pentecoste di Vézelay, un unicum nel panorama dei modelli medievali della comunicazione visiva," Arte medievale, n.s., 1, no. 2 (2002): 55-75, at 61-62; and Marcello Angheben, "Apocalypse XXI-XXII et l'iconographie du portail central de la nef de Vézelay," Cahiers de civilisation médiévale 41, no. 163 (1998): 209-40.

81. Hrabanus Maurus [sic], Allegoriae in universam Sacram Scripturam, in Migne, PL 112 (1852): cols. 884-85: "Abacuc capillo de Judaea in Babylonem transvectus esse perhibetur; per Abacuc, qui amplectens sive luctator interpretatur, Redemptor noster exprimitur, qui ut suos sibi amplectens luctam contra diabolum iniit: 'Erat autem Abacuc in Judam' et Christus spiritualiter ad Judaeos missus est. . . . Ille 'in campum iniens tulit messoribus:' et Christus ad Synagogam veniens praedicavit Judaeis. . . . Abacuc ergo capillo in Babylonem translatus, Danieli prandium, quod messoribus praeparaverat, attulit; et Redemptor noster per praedicatores suos verbum salutis Judaico populo destinatum, gentibus ministravit. 'Surrexit Daniel et comedit;' et populus gentium ab errore surgens ad fidem erigitur, et divinae doctrinae pabulo reficitur. Relicto Daniele, Abacuc in locum, unde translatus est, restituitur: et Christus plenitudine gentium completa ad Judaeos redibit, et tunc omnis Israel salvus fiet." On the authorship of this text, see André Wilmart, "Les Allégories sur l'Écriture attribuées à Raban Maur," Revue bénédictine 32 (1920): 47-56. For the passage cited, see Mauro Donnini, "Su alcune Allegoriae in universam Sacram Scripturam dello pseudo-Rabano Mauro," Mediaeval Sophia: studi e ricerche sui saperi medievali 11 (2012): 104-18, at 105-6, http://www.mediaevalsophia.net/11-gennaio-giugno-2012.
The homilies discussed above would seem to provide an effective guide for understanding the complex juxtaposition of different scenes on the portal, notwithstanding the fact that some features cannot be fully explained through these texts. For example, three of the apostles surrounding Christ hold scrolls instead of books (Fig. 8), but while such a combination of iconographic attributes for the apostles might seem unusual, it is not unique to Beaulieu. A comparable diversity of attributes is found, inter alia, in the first half of the twelfth century on the exterior of the choir of the Cluniac abbey of La-Charité-sur-Loire, on the facade of Notre-Dame-laGrande in Poitiers, and on a lintel in the Musée Sainte-Croix in the same city. ${ }^{82}$ At the same time, it seems likely that the visual organization of the tympanum at Beaulieu hints at a particular significance for these apostles who hold scrolls, given that some of the figures at the feet of Christ are pointing directly at them. It should be noted, too, that the second apostle from the right sports a long, forked beard (Fig. 2) like that of Daniel in the porch (Fig. 4), some of the seven men at the feet of Christ, and the figure on the opposite side of the tympanum whom I have identified as Hosea (Fig. 11). Yet this figure with the scroll is clearly one of the apostles, as he is nimbed, barefoot, and dressed exactly like his peers, whereas Hosea, unlike these twelve figures, is smaller in size and has a pointed hat.

These are only two of the elements in the portal that do not necessarily find an explanation in the homilies of Gregory the Great; the others are the identification of a figure on the left side of the porch, the sculptures on the trumeau, and the processional cross behind Christ in the tympanum. Some of these may nevertheless be related to Cluny. The first, to the left of the Daniel scenes, is a modern copy (Fig. 4). ${ }^{83}$ The extremely damaged state of the original defies identification, although proposals have included the enthroned Virgin, St. Benedict, or Daniel himself. ${ }^{84}$

82. La-Charité-sur-Loire: Neil Stratford, "La Charité-sur-Loire et Cluny," in Stratford, Cluny, 910-2010, 180-99. Poitiers, Notre-Damela-Grande: Milanesi, Bonifica delle immagini, 162-77, esp. 173. The lintel in the Musée Sainte-Croix was probably originally located in the abbey of Saint-Benoit, south of Poitiers. Pascale Brudy and Anne Bénéteau Péan, eds., Lâge roman: arts et culture en Poitou et dans les pays charentais, Xe-XIIe siècles (Montreuil: Gourcuff Gradenigo, 2011), 318. All the apostles hold scrolls in the lunette of the chapel Saint-Hilarian-Sainte-Foy (or Chapelle de Perse), Espalion: Angheben, D'un jugement à l'autre, 88-95.

83. Pêcheur and Proust, "Beaulieu-sur-Dordogne," 101. During the restorations, the damaged reliefs under the figure were interpreted as two lions.

84. By, respectively, Christe, "Le portail de Beaulieu," 64; Zink, "Moissac, Beaulieu, Charlieu," 148; and Besancon, "French Romanesque Portals," 293-94. 

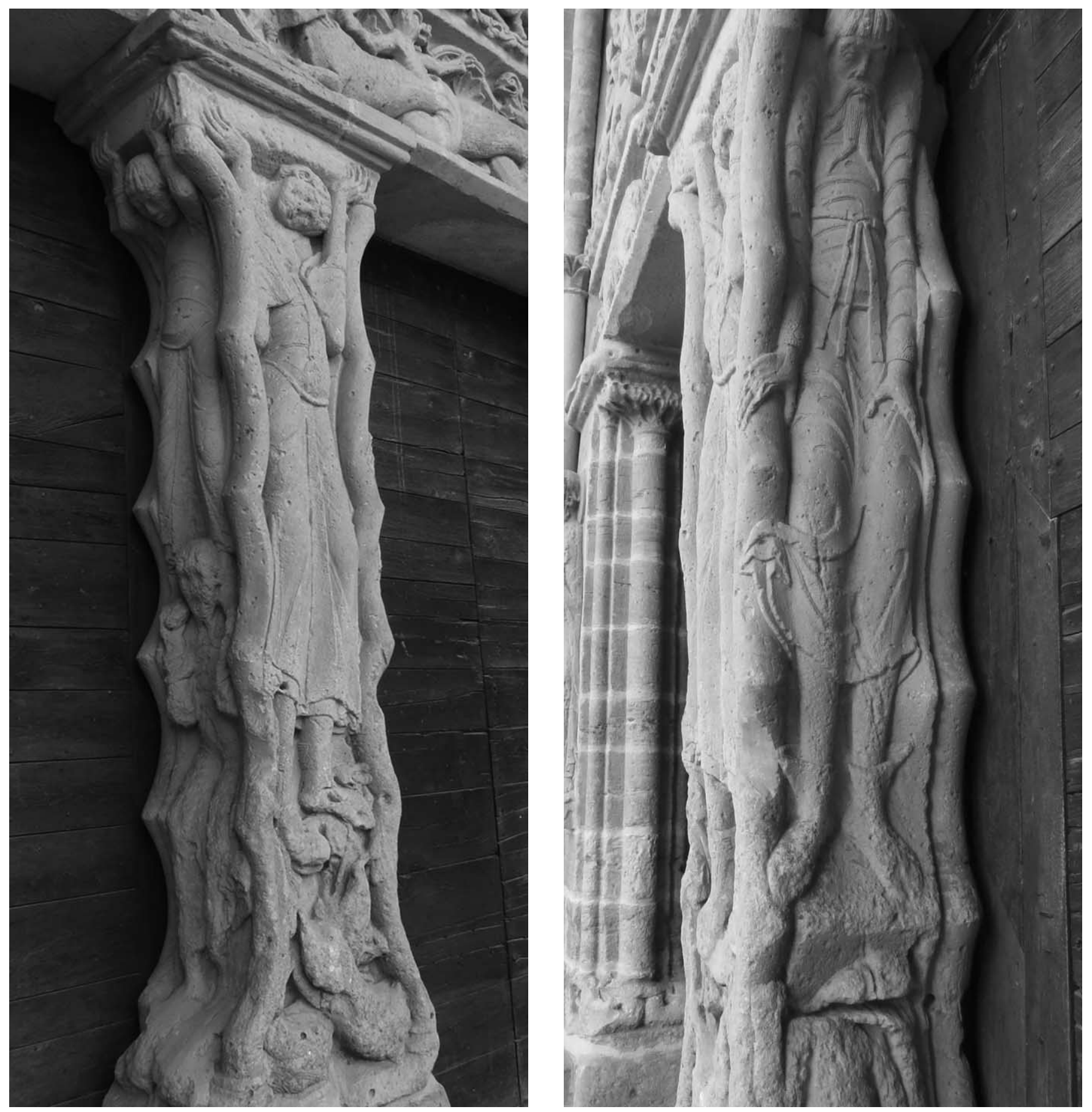

Figure 15. Trumeau, 1130-40, south portal, abbey church of Saint-Pierre, Beaulieu-sur-Dordogne. (a) front and west side, (b) east side (photo: author). See the electronic edition of Gesta for color versions of these images.

The portal is framed by jambs with St. Peter on the left and St. Paul on the right (Fig. 1), and their presence has been interpreted as conveying "the monastery's allegiance to the papacy." ${ }^{15}$ It seems more likely, however, that they provided yet another direct reference to Cluny. Peter and Paul were

85. Besancon, “French Romanesque Portals," 289. the patron saints of the Burgundian abbey, and their relics were preserved in Cluny's abbey church, which was described in contemporary sources as a basilica-reliquary of the two apostles. ${ }^{86}$

86. Iogna-Prat, Order and Exclusion, 80-82. In addition, as noted by Besancon ("French Romanesque Portals," 288n166), in a 
The monumental trumeau, damaged in its lower portion, presents three "scenes." On its front (south) face, a young man stands atop several beasts, his head bent and his hands supporting the weight of the tympanum above (Figs. 1, 15a). On the west side, a bearded man supports on his shoulder a beardless one who, with a gesture similar to that of the southfacing telamon, holds up the portal. Finally, on the east face of the trumeau a man with a long, forked beard, standing above a smaller man, supports the portal on his shoulders (Fig. 15b). French suggested that the bearded figures are prophets, but the lack of scrolls or inscriptions might refer, as Besancon argued, to the representation of "a generic prophet or to personify the Old Testament." ${ }^{37}$ The figure on the east side evokes the iconographic scheme of prophets carrying apostles on their shoulders but does not look like any examples known to me. ${ }^{88}$

Again, none of these depictions is explained by the homiletic texts; nor is the visualization of the processional cross behind Christ explicitly mentioned (Fig. 8). The latter, however, might be read in light of liturgical practices associated with Lent. The visual evidence for this is compelling. Whereas in the tympana at Conques and Saint-Denis the angels hold the cross behind Christ (Figs. 9, 10), at Beaulieu the gestures and bodily positions of the two celestial figures suggest that they are elevating it. This is echoed in the liturgy in two ways: not only was the cross an object of particular veneration at Cluny but also, following more general monastic practices, its adoration was at the core of the liturgical performance on Holy Friday, the day of the Crucifixion. ${ }^{89}$ According to the

donation to the abbey of Beaulieu (1097-1108) the donor Robertus promises "stabilitatem loci istius secundum regulam S. Benedicti et SS. apostolorum Petri et Pauli” (Deloche, Cartulaire de l'abbaye, 175-76). It is possible that the reference to the regula of the apostles could point not only to Cluny but also to the adoption of its liturgy. Even though the dedication of Beaulieu to St. Peter predates the abbey's connection to Cluny, the inclusion of the two apostles on its portal might reinforce the connection with the Burgundian abbey.

87. French, "Innovative Imagery" (1972), 98-103; and Besancon, "French Romanesque Portals," 288-93. Zink ("Moissac, Beaulieu, Charlieu," 160-64) suggested reading the trumeau as a visualization of the different ages of man, which might be understood in contrast to the representation of the eternal life presented in the portal above. Franzé ("Art et réforme clunisienne," 46) identifies these figures as prophets and apostles.

88. For this iconographic scheme and its interpretation, see, most recently, Marius B. Hauknes, "The Painting of Knowledge in Thirteenth-Century Rome," Gesta 55, no. 1 (2016): 19-47, at 34-38.

89. On the cult of the cross in Cluny, see Dominique Iogna-Prat, Etudes clunisiennes (Paris: Picard, 2002), 75-92. On the elevatio crucis, see Huglo, "L'office du Dimanche de Pâques," 157. For the cult of the cross in Rome, see Louis van Tongeren, "The Cult of the Cross in Late Antiquity and the Middle Ages: A Concise Survey of Its Origins and Development," Römisches Jahrbuch der Bibliotheca Hertziana 38 (2007-8): 59-75. For the use of processional crosses in Rome, eleventh-century Cluniac customs recorded in the Liber tramitis, during that celebration two priests or deacons were to leave the group of monks in the choir and, singing the verse "Popule meus," move to the area behind the altar, where the veiled cross was kept. In a chanted exchange with another pair of monks, they carried the cross before the altar, where it was elevated, unveiled, and adored by the entire community. ${ }^{90}$ This liturgical performance was very similar to that enacted for the feast of the Exaltation of the Cross (14 September), but in the latter, the meaning of the cross was transfigured through the act of adoration. ${ }^{91}$ The antiphon "Crucem tuam," solemnly sung during this performance, explains this metamorphosis from an instrument of the Passion to a sign of triumph: "We venerate your Cross, Lord, and we laud and glorify your holy resurrection because through the cross joy came in the entire world." 92

The act of unveiling the cross before adoration had a powerful significance. According to the Cluniac customaries, at the beginning of Lent all the reliquaries and crosses, regardless of size, were veiled, ${ }^{93}$ and they were revealed again only

see Sible de Blaauw, "Following the Crosses: The Processional Cross and the Typology of Processions in Medieval Rome," in Christian Feast and Festival: The Dynamics of Western Liturgy and Culture, ed. P. G. J. Post, G. Rouwhorst, A. Scheer, and L. van Tongeren (Leuven: Peeters, 2001), 319-43.

90. Liber tramitis, 80-81: "Deinde exeant duo sacerdotes uel diacones albis induti sustentantes crucem quae uelata esse debet retro altare canentes hunc uersum Populae meus. [Inter] haec contra sint ante altare duo albis uel tres similiter induti grecae respondentes Agyos o theos. Deinde clerus latinae prosequens decantet Sanctus deus sanctus fortis. Inde duo qui crucem sustentant mouentes / se deferant crucem aliquantulum inantea canentes iterum Quia eduxi te. Respondeant duo Agios o theos ac deinde clerus subsequatur Sanctus deus. Iterum duo qui crucem sustentant accedentes prope altare canant Quid ultra. Respondeant duo Agyos ac deinde clerus Sanctus deus. Tunc ipsi duo qui crucem tenent uenientes ante altare crucemque nudantes incipiant antiphonam Ecce lignum crucis. Finita antiphona chorus dicat Venite exultemus uel Beati immaculati. Tunc proiciant se omnes in terra adorantes sanctam crucem. Dumque adoratur, duo illi sustentent crucem, quosque alii ueniant et ipsi ad adorandum [uadant]. Et hos antiphonas decantent Crucem tuam, Dum fabricator. . . . Cum uero a loco ubi adorata est [crux] tollitur et in loco erigitur disposito, haec antiphona inponatur Super omnia ligna caedrorum." A similar liturgical performance is attested in the Consuetudines Cluniacensium antiquiores cum redactionibus derivatis, CCM 7, pt. 2, ed. Kassius Hallinger (Siegburg: Schmitt, 1983), 88-89.

91. Iogna-Prat, Études clunisiennes, 78.

92. Liber tramitis, 81. For the antiphon, see Thomas Forrest Kelly, The Beneventan Chant (Cambridge: Cambridge University Press, 1989), 210, 266. "Crucem tuam adoramus domine et sanctam resurrectionem tuam laudamus et glorificamus ecce enim propter crucem venit gaudium in universo mundo."

93. Liber tramitis, 55: "[De ritibus quadragesimalibus.] Luce apparescente secretarii cotidiana bancalia quae post dorsum fratrum 


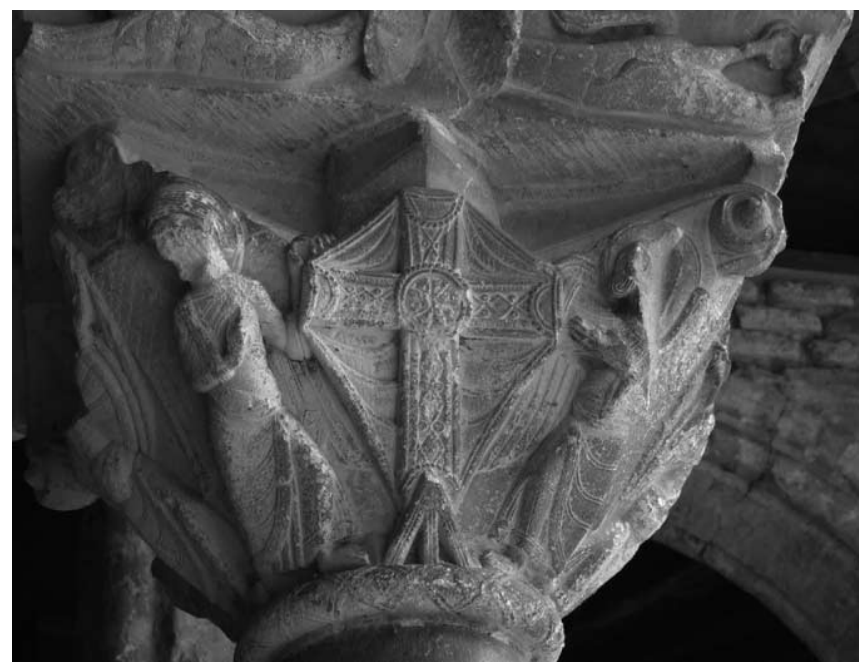

Figure 16. Exaltation of the Cross capital, 1100, cloister, Saint-Pierre, Moissac (photo: author). See the electronic edition of Gesta for a color version of this image.

during the celebrations of Holy Friday, before Terce. ${ }^{94}$ In the tympanum of Beaulieu the cross, unveiled and elevated by two angels, is a triumphal cross, decorated with a wreath where the two arms intersect. It suggests a visual comparison with the lost processional cross of Cluny that bore an inscription composed by Abbot Odilo (r. 994-1049). ${ }^{95}$ Even more interesting, in its visualization of the monumental triumphant cross the portal echoes one of the key moments of the Paschal triduum. The same, eternal resonance of the unveiling of the cross is also carved on a capital in the Cluniac cloister at Moissac, where the two crosses, the historical and the liturgical, are elevated by two pairs of angels. The latter, unveiled, is very similar to that of Beaulieu in the termination of the arms, their decorated borders, and the roundel or wreath at the center (Fig. 16). ${ }^{96}$

solitae erant stare suspendant. Capsulas cum reliquiis, crucifixos atque coronas uniuersas cum linteaminibus cooperiant, etiam paruissimas cruciculas."

94. Liber tramitis, 79: "Corone et omnes cruces discooperiantur ante Tertiam."

95. Liber tramitis, 259-60; and Susan Boynton, Shaping a Monastic Identity: Liturgy and History at the Imperial Abbey of Farfa, 10001125 (Ithaca, NY: Cornell University Press, 2006), 103-5.

96. Meyer Schapiro, “The Romanesque Sculpture of Moissac," Art Bulletin 13, no. 4 (1931): 249-350, at 291; and Cazes and Scellès, Le cloitre de Moissac, 48-49. For the Moissac cloister, see also Peter K. Klein, "Topographie, fonctions et programmes iconographiques des cloîtres: la galerie attenant à l'église" (105-56, at 107-16); Leah Rutchick, "Visual Memory and Historiated Sculpture in the Moissac Cloister" (190-211); and Maria Cristina Correia Leandro Pereira, "Syntaxe et place des images dans le cloître de Moissac" (212-19),

\section{Mirroring the Liturgy}

The identification of the depicted cross as a monumental processional object adds a new layer of meaning to the portal of Beaulieu. Its program does not simply visualize liturgical texts but also mirrors the eschatological thrust of the liturgy, prompting associations that directly relate to the portal as a liminal space experienced principally by the monastic community. The program of the portal is constructed around the temporal progression of Lent. The connection between Psalm 90 (91) and the three temptations of Christ does more than just recall the readings for the first Sunday of Lent. This psalm was part of the responsories sung every day during Lent, and it was sung in its entirety during the office of Holy Friday: it opened Lent and also celebrated its conclusion. ${ }^{97}$ Furthermore, the progression of the Lenten season is visually marked by the illustration of book 14 of Daniel, which relates to the Passiontide, up to Easter, which is powerfully represented by the tympanum.

At Cluny, the celebration of Easter was distinguished by a complex performative liturgy, recently investigated by Kristina Krüger. ${ }^{98}$ According to the Liber tramitis, the monastic community, on leaving the choir, walked in procession through the monastic buildings until they reached the atrium, in front of the church. After the senior monks stopped in the center, the singers intoned three times the antiphon "Crucifixum in carne," with the repetition "Nolite metuere." Entering the church, they chanted the antiphon "Christus resurgens" and the responsory "Maria Magdalena." After all the bells were rung, Terce was performed. ${ }^{99}$ The apex of this procession,

all in Der mittelalterliche Kreuzgang: Architektur, Funktion und Programm, ed. Peter K. Klein (Regensburg: Schnell \& Steiner, 2004).

97. Mario Righetti, Manuale di storia liturgica, vol. 2, Lanno liturgico: il breviario, 2nd rev. ed. (Milan: Àncora, 1955), 119.

98. Krüger, "Monastic Customs and Liturgy in the Light of the Architectural Evidence." A different reconstruction of the Easter procession is suggested in Roberto Ottolini, "Galilea, Cluny e reliquie: un rapporto originale? Odilone e il ruolo dei simboli," in $\mathrm{La}$ reliquia del sangue di Cristo: Mantova, l'Italia e l'Europa al tempo di Leone IX, ed. Glauco Maria Cantarella and Arturo Calzona (Verona: Scripta, 2012), 439-53.

99. Liber tramitis, 89-90: "Cantores autem inponant responsorium ex beata Maria quale uelint condecens uenientibus sic per ordinem: In primis aquam sanctam, crucem; atque [ueniant] sacerdotes dicendo orationes per officinas, deinde duae cruces, in medio earum crucifixus, subsequantur candelabra bina, unus inter ea textus, similiter duo alia candelabra sequentia cum texte euangelii. Ex tunc adiungantur illi duo cum regalibus signis ${ }^{* *}$, dein magistri cum infantibus, abbas post eos, alii[s] senioribus uenienti[bus] duo et duo sicut priores sunt. Ita uero illis egredientibus dicat sacerdos orationes in domo infirmorum. Sicque ueniat ante aram sanctae Mariae dicens hunc uersum In resurrectione tua Christe [et] orationem de 
according to the customaries, was the station in front of the portal at the place called Galilaea. ${ }^{100}$ In medieval liturgical exegesis this word not only signifies where Christ announced he would meet the disciples after his Resurrection but also, in an eschatological perspective, marks the place of the final encounter with Christ at the end of time. ${ }^{101}$ This latter concept once again finds an important correspondence in the liturgical readings of the Cluniac Lectionary, in particular Gregory the Great's homily incorporated into the twelfth reading of Easter:

It is aptly said of our Redeemer that: "He is going on ahead of you into Galilee. You will see him there, as he said to you." Galilee is interpreted, "the passing has been completed." In truth our Redeemer had now passed from his passion to his resurrection, from his death to life, from punishment to glory, from corruption to incorruption. After his resurrection he was first seen by his disciples in Galilee, because we will happily see the glory of his resurrection later if we now pass from vices to the height of virtue. And so he who was proclaimed at the sepulchre was to be seen at "the passing," because he who is acknowledged on the occasion of his physical death is seen in "the passing" of his heart. ${ }^{102}$

Resurrectionem quae conueniat. Exeuntes uero sicut uenerunt ita eant. Conuenientes autem in atrio ante ianuam monasterii stent ordinatim ut uenerunt, in medio seniores sicut mos est in choro stare. Tunc armarius annuat cantoribus quibus ei uisum fuerit, ut conueniant in medio post infantes inponantque hanc antiphonam Crucifixum in carne ter cum repetitione Nolite metuere. Intrantes aecclesiam paraphonista incipiat antiphonam Christus resurgens uel responsorium Maria Magdalena. Pulsantibus omnibus signis dicta oratione agant Tertiam." This same procession is mentioned with minor differences in other Cluniac customaries: Krüger, "Monastic Customs and Liturgy in the Light of the Architectural Evidence," 206-9.

100. In another Cluniac customary, the so-called Bern manuscript, the word Galilaea also occurs in the description of the Easter procession: Krüger, "Monastic Customs and Liturgy in the Light of the Architectural Evidence," 208.

101. Krüger, Die romanischen Westbauten in Burgund und Cluny, 272-81.

102. BnF, NAL 2246, fol. 51r: "Bene aut(em) de Rede(m)ptore $\mathrm{n}$ (ost)ro dicitur: $\mathrm{P}$ (rae)cedit vos in Galilaeam, ibi eum videbitis, sicut dixit vob(is). Galilaea namq(ue) transmigratio facta interp(re)tat(ur). Iam quippe Redemptor $\mathrm{n}$ (oste)r a passione ad resurrectione $(\mathrm{m})$, a morte ad vita(m), a $\mathrm{p}(\mathrm{o})$ ena ad $\mathrm{gl}($ ori)am, a corruptione ad incorruptionem transmigraverat. Et prius post resurrectionem in Galilaea a discipulis videtur, quia resurrectionis eius gl(ori)am post leti videbimus, si modo a viciis ad virtutum celsitudine (m) transmigramus. Qui (er)go in sepulchro nuntiatur, in transmigratione ostenditur, quia is qui in mortificatione carnis agnoscitur in transmigratione mentis videtur." Gregory the Great,
Just as Galilee is the eternal meeting place between Christ and his disciples-that is, the eschatological transmigration-so the Galilaea, the liminal space in front of the portal of the church, was the culmination of the Easter procession in Cluny. The term Galilaea denoted, in the Cluniac sphere, a two-story covered narthex in front of the church; its upper floor, not open to the nave, was the setting for a continuous sequence of masses for the commemoration of the dead. ${ }^{103}$ The liturgical relevance of the Galilaea was not restricted to the celebration of Easter. At Cluny, a similar procession was performed every Sunday, but with a significant variation: the officiating priest and the community of monks followed two different routes before meeting in front of the main portal of the church and celebrating, again, the station in the Galilaea. ${ }^{104}$

Krüger has recently reconstructed these processional pathways in Cluny based on the three eleventh-century customaries. The monastic community, leaving the church through the door in the south transept, celebrated the first station in the chapel of St. Mary and then, moving into the cloister, held the second station in front of the dormitory (in the east gallery), the third before the refectory (in the south gallery), and finally arrived at the area in front of the portal (Galilaea). ${ }^{105}$ Could a similar procession have been performed in the monastic setting of Beaulieu, and, if so, how might it have related to the images in its portal?

An engraving in the Monasticon Gallicanum, a collection of engravings of Benedictine monasteries in France, shows the topography of Beaulieu Abbey after the seventeenthcentury reconstructions. The cloister, flanking the north wall of the church, is at the core of the monastic settlement. ${ }^{106}$ This mirrors the medieval layout, as attested by the traces of corbels on the exterior of the north flank of the church, perhaps intended to support the roof of the cloister gallery, and by the presence of the chapter house adjacent to the north arm of

Homiliae in Evangelia, 176-77; and Hurst, Forty Gospel Homilies, 160. This connection is suggested in Krüger, Die romanischen Westbauten in Burgund und Cluny, 284.

103. Krüger, Die romanischen Westbauten in Burgund und Cluny; eadem, "Monastic Customs and Liturgy in the Light of the Architectural Evidence"; and eadem, "Architecture and Liturgical Practice: The Cluniac Galilaea," in The White Mantle of Churches: Architecture, Liturgy, and Art around the Millennium, ed. Nigel Hiscock (Turnhout: Brepols, 2003), 139-59. See also Luigi Carlo Schiavi, Il Santo Sepolcro di Milano da Ariberto a Federico Borromeo: genesi ed evoluzione di una chiesa ideale (Pisa: ETS, 2005), 182-87.

104. Krüger, "Monastic Customs and Liturgy in the Light of the Architectural Evidence," 206-9.

105. Ibid., 195.

106. Michel Germain, Monasticon Gallicanum: collection de 168 planches de vues topographiques représentant les monastères de l'Ordre de Saint-Benoit (Paris: Palmé, 1871), pl. 30. 


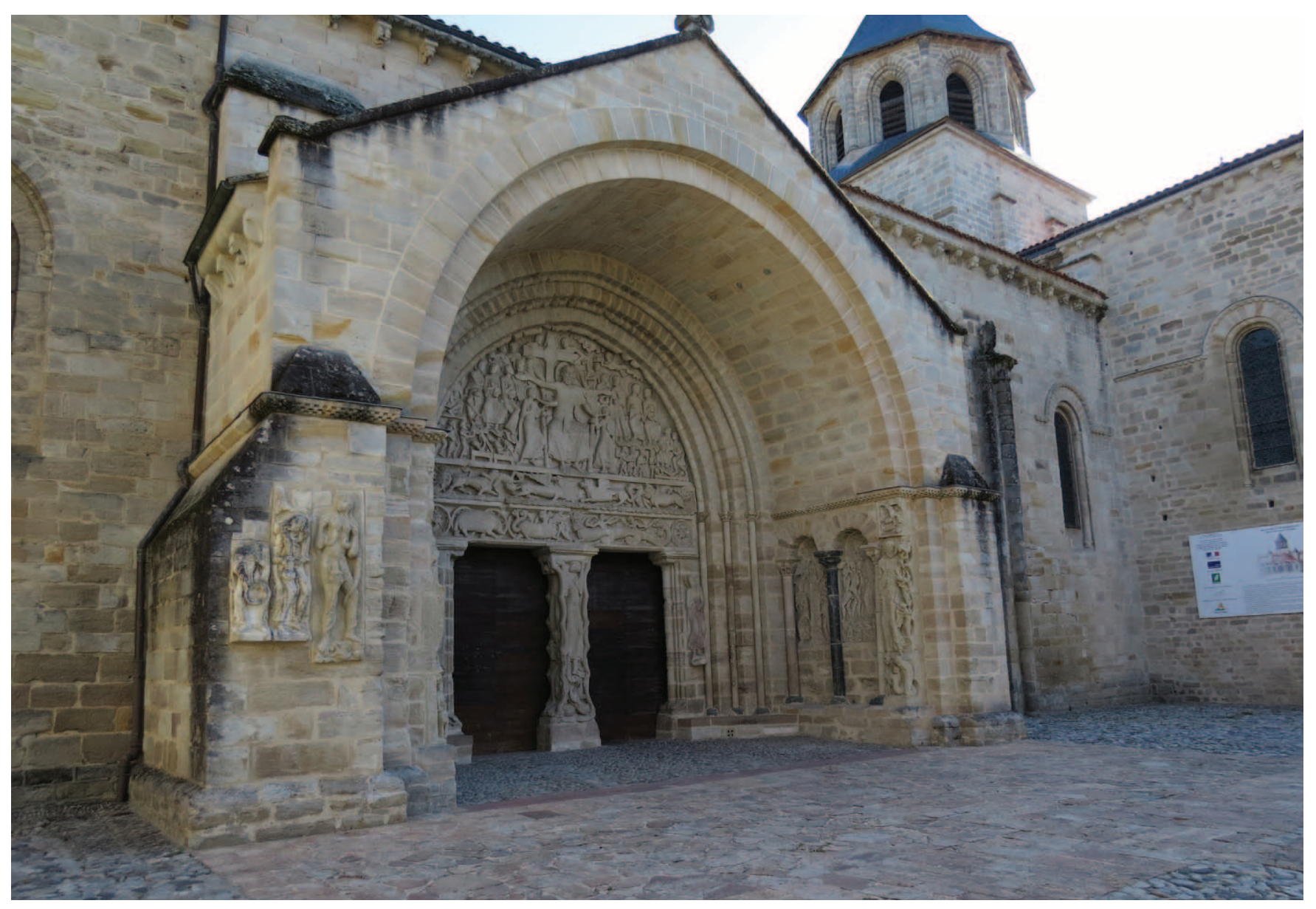

Figure 17. South portal and porch, view from the southwest, 1130-40, abbey church of Saint-Pierre, Beaulieu-sur-Dordogne (photo: author).

the transept, dated by Pêcheur and Proust to the end of the twelfth century. ${ }^{107}$ If the solemn processions at Beaulieu followed a sequence similar to that at Cluny, its spatial and topographical progression could be hypothetically reconstructed as follows.

The monastic community, after leaving the choir (Fig. 5a), would have progressed into the cloister through a small door (now walled up) located in the first bay of the north aisle of the church, next to the crossing. After holding the stations in the cloister, they would reenter the church through the same door (Fig. 5b). ${ }^{108}$ From there, two possible pathways led to the monumental carved portal (Fig. 5c): they could either process through the nave and reach the portal from the interior or, moving south and crossing the transept, leave the church

107. Pêcheur and Proust, "Beaulieu-sur-Dordogne," 94.

108. This portal contains a carved lintel possibly dating to the eleventh century (ibid., 92). through the small door at its south end (Fig. 5d). ${ }^{109}$ The small size of these doors does not preclude their possible liturgical function, as their scale is similar to that of the portal still extant at Charlieu, which connected the cloister there with the Galilaea. ${ }^{110}$ At Beaulieu, the portal of the south transept arm likely gave access to an area contained within the monastic enclosure. ${ }^{111}$

109. This access, although modified during the fifteenth century, is original (ibid., 84).

110. Krüger, "Monastic Customs and Liturgy in the Light of the Architectural Evidence," 197.

111. The engraving of the Monasticon Gallicanum shows that this portal gave access to the cemetery between the transept and the choir. A tower still extant a few meters to the east of the main apse, dated between the twelfth and the thirteenth century and part of the abbey precinct, suggests that this area was inside the monastic enclosure during the Middle Ages. Garrigou Grandchamp, "Introduction à l'architecture domestique urbaine," 34; and Barrière, Boisset, Proust, and Ribiéras, Beaulieu sur Dordogne, 32. 
Connections among liturgical performance, liturgical texts, and the program of the portal as it was experienced by the monks find further support in the concept of Galilaea itself. According to Rupert of Deutz (1070/80-1129/30), a monk at Saint-Laurent in Liège, which had adopted Cluniac customs, the meeting of the priest and the monks before the portal at the end of the festive Sunday procession commemorates and reiterates every week the eternal meeting of Christ and his apostles. ${ }^{12}$ Saint-Pierre at Beaulieu does not have a proper Galilaea, at least as it has been defined architecturally by Krüger, but the concept of the Galilee underpins the liturgical basis of the sculptures in the porch (Fig. 17). After the three temptations (Matt. 4:12), "when Jesus had heard that John was delivered up, he retired into Galilee," and the Gospel reading for Tuesday Passiontide, after the fourteenth book of Daniel, begins, "After these things Jesus walked in Galilee; for he would not walk in Judea, because the Jews sought to kill him" (John 7:1). ${ }^{113}$ For the monastic community of Beaulieu, accustomed to the liturgical readings of the year, the porch sculptures would have served as a "recollective cue" to the concept of Galilaea and their own reiterative process of meeting Christ. ${ }^{114}$

This recollective cue could have been obtained through the communal, performative nature of the liturgical processions in the physical space of the porch, the likely site of the Galilaea station; the porch itself would have served as liturgical stage. The carvings of three vices (Fig. 7) may have been perceived not only as a stimulus for meditation but also, as discussed recently in relation to the figure of Luxuria in the porch at Moissac, to visualize "phantasies from the mind in order to neutralize their destructive power, stimulating penance and conversion." ${ }^{115}$ If these sculptures were originally placed on the front of the right (east) buttress of the porch, the turn of their heads would naturally have directed the gaze of the beholders to the monumental carving of Christ over the beasts (Fig. 6), which, in turn, through the twisted pose of his body, would have introduced the viewer to the porch, where Christ over beasts is also visualized in the tympanum (Figs. 8, 17). The structure of the porch and the visual arrangement

112. Krüger, Die romanischen Westbauten in Burgund und Cluny, 265-68.

113. Liber comitis, col. 502: "Ambulans Jesus in Galilaea, usque propter metum Judaeorum."

114. For the multilayered interactions between images and memory, see Carruthers, Craft of Thought, esp. 103, for the expression "recollective cue."

115. Thomas E. A. Dale, "The Nude at Moissac: Vision, Phantasia, and the Experience of Romanesque Sculpture," in Maxwell and Ambrose, Current Directions in Eleventh- and Twelfth-Century Sculpture Studies, 61-76, at 66. of the scenes on its flanks suggest a kinetic approach toward the church entrance, a physical movement that mirrors the temporality of the liturgy and the physicality of its liturgical processions. Christ over the beasts on the right flank precedes the three temptations of Christ, just as in the liturgical readings for the first Sunday of Lent, Psalm 90 (91) precedes the Gospel of Matthew.

The progression from exterior to interior is highlighted by the gestures of Christ's body in the temptation scenes (Fig. 3). In the first scene on the right (third temptation) he stands facing the portal of the church; in the second, extremely lacunose representation of the second temptation, Christ's body faces the beholder, and while he raises his right hand in front of the devil, his left points toward the entrance; and in the final scene (first temptation), Christ is depicted walking into the church, mirroring the processional movement of the monastic community. In a similar way, on the opposite side of the porch (Fig. 4), the representation of the angel carrying Habakkuk to Daniel impresses a dynamic movement from left to right toward the church door.

As Easter marks the end of Lent, so the tympanum is the culminating point of the visual progression made manifest in the porch (Fig. 8). It represents the complex interaction of different meanings, in particular the Resurrection of Christ, as mediated through the readings for Easter. The angels that flank Christ are perhaps those associated by Rupert of Deutz, in his Liber de divinis officiis, with the celebrations of the night before Easter: "the angelic crowd of the sky exults, the trumpet of salvation sounds, the earth rejoices, the mother-Church exults, and the entire hall reverberates the magnificent name with voices of people."116 The gates of hell have been smashed, the doors of heaven have been opened, the resurrection of the dead is connected with the Resurrection of Christ, and the eschatological perspective for the Jews is depicted at the feet of the apostles. As Rupert further states, commenting on the triduum:

Let us march out from that darkness which covered the earth from the sixth hour to the ninth, which covers the heart of the Jews. Let us march out from the darkness and look in intense contemplation to the one who called

116. Ruperti Tuitiensis Liber de divinis officiis, ed. Hrabanus Haacke (Turnhout: Brepols, 1967), 207: "Iure ergo nunc angelica turba caelorum exsultat, tuba salutaris insonat, gaudet tellus, mater ecclesia laetatur, et omnis aula diuini nominis magnis resultat populorum uocibus." 
you to him in his admirable light: the supreme king, the peaceful king with his crown covered with thorns. ${ }^{117}$

The tympanum at Beaulieu visualizes this triumph over death and hell: the cross is elevated, and an angel at the upper right carries Christ's sumptuous kingly crown (not, as in Rupert's text, the crown of thorns).

\section{Conclusions}

When read in light of Cluniac liturgical sources, the portal of Saint-Pierre at Beaulieu-sur-Dordogne reveals a deeper level of meaning: many of its iconographic inconsistencies become clearer, and the portal acquires a new significance in the debate on the connections among images, liturgy, and performance. The porch constitutes a careful and accurate visual commentary on certain readings for Lent, and it resonates with the concept of Galilaea in its intimate Cluniac sense as the liminal space for the liturgical performance that hosts the final and eternal meeting of Christ and his apostles, echoed and performed every Sunday in a festive monastic procession. ${ }^{118}$ Rupert of Deutz described the procession this way:

We mean, with the order of the procession, that we need to go out into the Galilaea, which is in transmigration to see the Lord with his apostles, of course, as we are no longer the old men, as we were, but we walk in the newness of life. And we always follow our priests, which are in front of us, as if it were Jesus to Galilee, and the very same place where we end the procession with the supreme, the last and more important station, is correctly named by us Galilaea. ${ }^{119}$

When the collective liturgy is performed, the boundaries between the actions of the monastic community and the events that the rituals commemorate are blurred.

The carvings on the Beaulieu portal find their most profound explanation in the liturgy. They not only visualize the progression of Lent, from its beginning to Easter, but also show a close dialogue between texts and images, both in terms of quotations carved in the scenes of the temptations of Christ and in their strict adherence to the Old Testament narration, as in the Daniel scenes. In its selection of images, the portal demonstrates a mediated visual response to the liturgical readings as they were combined in the late eleventhcentury Cluniac Lectionary: the ways the images relate to the readings explain many of the anomalies of the program and offer a new perspective on the depicted Jews, included here in the framework of redemption. Yet the connection with Cluny goes beyond the carving of scenes that responded to texts assembled in the lectionary: the portal also gestures toward the liturgical concept of Galilaea as it was elaborated in the Burgundian abbey. Furthermore, the synesthetic experience of liturgical performance permeates the portal program, mirroring and amplifying the eschatological meaning of the liturgy that was likely performed in front of it.
117. Ibid., 199: "Egredimini, inquam, de tenebris illis, quae super terram factae sunt ab hora sexta usque in horam nonam, immo de illis, quae per istas significatae sunt et nunc operiunt faciem cordis Iudaeorum. De his ergo tenebris exite et uidete intenta contemplatione illum, qui uos uocauit in admirabile lumen suum: Regem magnum, regem pacificum in diademate spineo."

118. Regarding the lack of inscriptions on the portal of Cluny III, Kristina Krüger has recently suggested that liturgical chants and orations delivered in the processions should be considered "a sort of explanatory commentary concerning the sculpture": Krüger, "Limage et les mots: réflexions sur la presence ou l'absence d'inscriptions aux portails romans sculptés," in La mémoire des pierres: mélanges d'archéologie, d'art et d'histoire en l'honneur de Christian Sapin, ed. Sylvie Balcon-Berry, Brigitte Boissavit-Camus, and Pascale Chevalier (Turnhout: Brepols, 2016), 359-70, at 359.
119. Haacke, Ruperti Tuitiensis Liber de divinis officiis, 158: "Singulis dominicis a prima sabbati, qua Dominus resurrexit, dedicatis hoc pro nobis processionis ordine significamus, quod in Galilaeam, id est in transmigrationem ad uidendum Dominum cum apostolis eius exire debeamus, scilicet, ut non simus uetusti homines, quod fuimus, sed in nouitate uitae ambulemus. Unde semper in huiusmodi processionibus prelatos nostros praeeuntes quasi Dominum in Galilaeam sequimur, et locus ipse, quo processionem suprema statione terminamus, recte a nobis Galilaea nuncupatur." 